NBER WORKING PAPER SERIES

\title{
DO YOUTHS SUBSTITUTE ALCOHOL AND MARIJUANA? SOME ECONOMETRIC EVIDENCE
}

Frank J. Chaloupka

Adit Laixuthai

Working Paper No. 4662

\author{
NATIONAL BUREAU OF ECONOMIC RESEARCH \\ 1050 Massachusetts Avenue \\ Cambridge, MA 02138 \\ February 1994
}

Research for this paper was supported by Grants RO1 DA07111 from the National Institute on Drug Abuse and RO1 AA 08359 from the National Institute on Alcohol Abuse and Alcoholism to the National Bureau of Economic Research. The authors are grateful to Patrick M. O'Malley and Jerome J. Hiniker of the University of Michigan's Institute for Social Research for providing restricted data sets from the Monitoring the Future surveys of 1982 and 1989 containing county identifiers. The authors are also indebted to Paul Taubman for providing the marijuana price data and to Henry Saffer, Michael Grossman, Gregory Bloss, Mark Showalter, and session participants at the 1992 Southem Economics Association meetings in Washington, D.C. and the 1993 Westem Economic Association meetings in Lake Tahoe, NV for comments on earlier drafts. Any opinions expressed in this paper are those of the authors and not those of the NIDA, NIAAA, UIC, or the National Bureau of Economic Research. This paper is part of NBER's research program in Health Economics. 


\title{
DO YOUTHS SUBSTITUTE ALCOHOL AND MARIJUANA? SOME \\ ECONOMETRIC EVIDENCE
}

\begin{abstract}
Data from the 1982 and 1989 Monitoring the Future Surveys are used to examine the substitutability of alcoholic beverages and marijuana among youths. Beer prices and minimum legal drinking ages are used as measures of the full price of alcohol, while an indicator of marijuana decriminalization and its money price capture the full price of marijuana. Results indicate that drinking frequency and heavy drinking episodes are negatively related to beer prices, but positively related to the full price of marijuana. The implications of this substitution for one of the consequences of youth substance abuse, driving while intcxicated, is examined using information on youth non-fatal accidents taken from the surveys and on youth fatal motor vehicle accidents constructed from the Fatal Accident Reporting System. These results indicate that the net effect of an increase in the full price of alcoholic beverages on the probability of a youth traffic crash is negative. However, the opposite is found for marijuana. That is, the results imply that the reduction in accidents resulting from substitution away from alcoholic beverages and other intoxicating substances to marijuana as its full price is lower more than offsets the increase in accidents related to marijuana use.
\end{abstract}

Frank J. Chaloupka Department of Economics (M/C 144) University of Illinois at Chicago 601 S. Morgan Street, 21st Floor Chicago, IL 60607-7121 and NBER
Adit Laixuthai

Health Resources Management (M/C 923)

School of Public Health East

University of Illinois at Chicago

Box 6998

Chicago, IL 60680 


\section{Introduction}

Youth drinking and alcohol abuse have been a focus of government policy since the mid 1970's. When the 26th amendment to the Constitution lowered the voting age to 18 years, a number of states followed by also lowering their minimum legal drinking ages. The consequent increase in youth alcohol abuse, particularly in drinking and driving, led many states to rethink this policy. By 1984, the federal government became involved in what had traditionally been left up to states to decide by enacting the Federal Uniform Drinking Age Act. This act pressured states into raising all legal drinking ages to 21 years or suffer the penalty of losing part of the highway funds they received from the federal government. By 1988, all states had complied. The higher drinking ages succeeded in reducing youth alcohol use and abuse (for example: Coate and Grossman, 1988: Saffer and Grossman, 1987). However, drinking, heavy drinking, drunken driving, and other measures of youth alcohol abuse remain stubbornly high. For example, in 1991, approximately 30 percent of high school seniors report at least one heavy drinking episode (five or more drinks on a single occasion) at least once in the previous two weeks.

Three recent econometric studies suggest that part of the reason for the persistently high level of youth drinking may be the success of the "War on Drugs", particularly with respect to marijuana. In the first of these, John DiNardo and Thomas Lemieux (1992) use state level tabulations for 43 states of marijuana and alcohol use taken from the annual Monitoring the Future (MTF) survey of high school seniors over the years from 1980 through 1989 to look at the effects of increases in legal drinking ages. 
They find that the higher legal drinking ages did reduce youth alcohol consumption, as expected. However, they find that the lower alcohol consumption was accompanied by an almost one-for-one increase in marijuana consumption. They conclude that this unintended consequence is attributable to standard substitution effects.

In two studies, Karyn Model looks at the effects of marijuana decriminalization on drug related hospital emergency room episodes, (1993) and violent crime (1991). Based on the hospital emergency room data, she concludes that marijuana decriminalization leads individuals to substitute away from alcohol and other illegal drugs towards marijuana. She finds that emergency episodes related to marijuana use are higher in states which have decriminalized, while those related to alcohol and other illegal drug use are lower. Similarly, she finds that lower violent crime rates, particularly homicide rates, are associated with marijuana decriminalization. Since a high percentage of violent crimes are alcohol related, she attributes the lower crime rates in states which have decriminalized to substitution away from alcohol toward marijuana. These findings conflict somewhat with those of Johnston, O'Malley, and Bachman (1987) based on the 1975 through 1980 Monitoring the Future surveys of high school seniors and their subsequent followups. They find that marijuana consumption and attitudes towards marijuana among youths and young adults are little changed in the early years after decriminilization in the seven states which decriminalized marijuana during their sample.

This paper adds to the limited econometric literature addressing the question of substitution between marijuana and alcohol. Youth drinking and heavy drinking, taken from the 1982 and 1989 Monitoring the Future surveys, are estimated as functions of the 
price of alcohol, legal drinking ages, and the price of marijuana. In addition, the probability of a youth traffic accident, an outcome related to both alcohol and drug abuse, is estimated. Finally, state level youth motor vehicle accident rates are examined using data from the Fatal Accident Reporting System (FARS).

\section{Youth Alcohol Consumption}

\section{A. Analytical Framework}

The model employed in this study is based on Siegel's (1989) hypothesis that individuals consume drugs and alcohol in an attempt at mood alteration. Thus, an individual's utility at any given time is assumed to be a function of that person's level of "intoxication" (I), as well as a composite of other consumption goods $(X)$ :

$$
U=u(1, X)
$$

where $u_{i}>0$ and $u_{i}<0, i=1, X$.

Intoxication is produced by consuming alcohol $(A)$, marijuana $(M)$, and/or other drugs (D) each of which have positive but diminishing marginal productivity:

$$
I=I(A, M, D)
$$

Maximizing utility, subject to the intoxication production function and an appropriate 
budget constraint yields the demands for alcohol, marijuana, and other drugs:

$$
A=A\left(P_{A}, P_{M}, P_{D}, P_{X}, Y, Z\right)
$$

$$
M=M\left(P_{M}, P_{A}, P_{D}, P_{X}, Y, Z\right),
$$

and:

$$
D=D\left(P_{0}, P_{A}, P_{M}, P_{X}, Y, Z\right)
$$

where $P_{A}, P_{M}, P_{D}$ and $P_{x}$ are the prices of alcohol, marijuana, other drugs, and other goods, respectively, $Y$ represents the youth's income, and $Z$ is a vector which captures the youth's tastes and productive efficiency.

\section{B. Data}

Alternative versions of equation (3) are estimated below using data on youth alcohol consumption taken from the 1982 and 1989 Monitoring the Future surveys of high school seniors. These surveys, described in detail by Johnston, et al., (1987), focus on the use of illegal drugs, alcohol, and cigarettes, and are conducted in the spring of the youth's senior year. These data are collected directly from the students. Parents were not present during the interviews and were not informed about the responses of their children. As part of a special agreement, variables measuring youth alcohol consumption were made available as part of a restricted data set which includes identifiers for each 
youth's county of residence.' In addition, a variety of socioeconomic and demographic information was provided.

Three alternative measures of the frequency of youth alcohol consumption were constructed from the categorical measures obtained in the surveys. ${ }^{2}$ The distribution of these measures, the construction of which is described below, is presented in Table 1.

The first consumption frequency measures looks at alcohol consumption during the previous year and is measured as follows: abstainers are defined as youths with no drinking occasions in the past year; infrequent drinkers are defined as youths with between 1 and 9 drinking occasions in the past year; fairly frequent drinkers are defined as youths with 10 to 39 drinking occasions in the past year; and frequent drinkers are defined as youths with 40 or more drinking occasions in the past year. The dependent variable indicating the frequency of alcohol consumption in the past year is defined as $0,1,2$, and 3 for abstainers, infrequent drinkers, fairly frequent drinkers, and frequent drinkers, respectively.

The second captures drinking in the past 30 days, and is defined as 0 for abstainers (no drinking occasions in the past 30 days), 1 for infrequent drinkers ( 1 to 5 drinking occasions in the past 30 days), 2 for fairly frequent drinkers (6 to 9 drinking occasions in the past 30 days), and 3 for frequent drinkers (10 or more drinking

\footnotetext{
' Unfortunately, individual level data on marijuana and other drug consumption is unavailable in the restricted versions of the Monitoring the Future data sets provided to the authors by the University of Michigan's Institure for Social Research.

${ }^{2}$ More detailed alcohol specific information is collected in five or six additional questionnaires, each of which is completed by a fraction of the total sample. These data include beverage specific alcohol consumption, attitudes towards alcohol, and various other measures.
} 
occasions in the past 30 days).

The final drinking variable is an indicator of heavy drinking. This variable is defined as one if the youth had at least one drinking occasion in the two weeks prior to the survey in which he/she consumed five or more drinks, and is defined as zero otherwise.

The alcoholic beverage prices are taken from the quarterly reports of the American Chamber of Commerce Researchers Association (ACCRA). The ACCRA surveys between 200 and 300 cities quarterly and collects information on the prices of a number of consumer goods, including beer, wine, and distilled spirits. ${ }^{3}$ In addition to prices, the ACCRA constructs a city specific cost-of-living index for each of the cities in its quarterly reports. The results presented below use the price of beer as the measure of alcoholic beverage prices. The beer price is chosen since beer is the most heavily consumed alcoholic beverage and because beer is the beverage of choice among youths." The ACCRA beer price and city specific cost-of-living index are matched to the surveys by county in each of the first two quarters of 1982 and 1989." Similarly, the quarterly national Consumer Price Index for the first two quarters of 1982 and 1989 is added to the

\footnotetext{
3 In 1982, prices are obtained for a 750ml bottle of Seagram's 7-Crown, a 6-pack of Budweiser or Schlicz, and a 750ml botrle of Paul Masson Chablis. In 1989, the reports include prices of a 1 liter bottle of J\&B Scotch, a 6-pack of Budweiser of Schliz, and a 1.5 liter bottle of Paul Masson Chablis. A careful effort was made to construct a standardized series of prices for beer, wine, and distilled spirits. Detailed information on the construction of this series is available from the authors.

- All equations presented below were also estimated using a weighted average price of beer, wine, and spirits, or the beer tax as alternative measures of alcoholic beverage prices. These results, which are similar to those obtained for beer prices, are available upon request.

SThe price assigned to each youth in each quarter is the price in the ACCRA survey city nearest the youth's county of residence. All equations presented below were reestimated using subsamples of the MTF surveys based on the quality of the price match. The results obtained for these subsamples were consistent with those obtained in the full samples and are available upon request.
} 
survey data. Real beer prices are the constructed by defiating the quarterly prices by both the national CPI and the ACCRA cost-of-living index and then taking the simple average of the resulting real prices for the first and second quarters.

The average minimum legal drinking age for low alcohol beer is added to the survey data as an additional measure of the full price of alcoholic beverages." While almost all youths surveyed are below 18 years of age, and thus unable to legally purchase alcoholic beverages in any state, youths residing in states with higher minimum ages will face greater difficulty in obtaining alcoholic beverages than their counterparts in states where the legal age is lower.

In addition to the own-state minimum legal drinking age, a dichotomous indicator equal to one if the youth resides in a county within 25 miles of a state with a lower legal age is added to the data. This variable is equal to zero if the youth does not live in a county within 25 miles of another state or if the drinking age in the youth's state of residence is as low or lower than that in nearby states. The inclusion of this variable is an attempt to capture potential border crossing by youths from high age states to nearby lower age states to obtain alcohol. ${ }^{\top}$

Two variables are added to the data to capture the full price of marijuana. The first

\footnotetext{
The minimum legal drinking age is the weighted average of the legal ages in place during the first two quarters of the year in which the youth is surveyed. The construction of this variable accounts for the grandfather clauses many states adopted when raising their legal ages for all alcoholic beverages to 21 years to comply with the Federal Uniform Drinking Age Act of 1984. While all states had complied with this law by 1989, grandfather clauses in some states kept the effective legal age below 21 years in some states until mid-1989. Similar variables were constructed for high alcohol content beer and for distilled spirits. The choice of the drinking age variable had little impact on the resulting estimates.

${ }^{7}$ This variable takes on a value of zero for all youths in 1989 since the grandfather clauses which keep effective drinking ages in some states below 21 apply to state residents only. Hence, this variable is omitted from the equations estimated using the 1989 sample only.
} 
is a dichotomous indicator which is equal to one if marijuana possession is decriminalized in the state in which the youth resides and is equal to zero otherwise. Although the possession and use of marijuana is not fully legal in states which have decriminalized it, the expected penalties are well below those in states where marijuana remains criminalized. Thus, marijuana consumption is expected to be higher in states which have decriminalized. If marijuana and alcohol are substitutes for one another, then youths residing in states which have decriminalized marijuana are expected to drink less than youths in states where the penalties for marijuana possession and/or use are much higher.

The second variable is a measure of the money price of marijuana. These data come from the Drug Enforcement Agency's System to Retrieve Information from Drug Evidence (STRIDE) database. Prices for both commercial grade marijuana (the dominant strain of marijuana in U.S. markets) and sinsemilla (a more potent strain of marijuana) are reported at both the wholesale and retail levels. The wholesale prices are reported in dollars per pound, while the retail prices are reported in dollars per ounce.

There are several problems with using these marijuana price data in this research. First, the prices are reported for at most 19 major metropolitan areas. To match the price data with the survey data, the following strategy was employed: if the youth resides in a county which includes a city in the STRIDE database, then the price in that city is used for the marijuana price (this is considered a "perfect" match); if there is no "perfect" match, then the price in the nearest city within the same state from the STRIDE database to the youth's county of residence is used as the marijuana price (two levels are defined 
for the quality of this match - a "border" match is one where the STRIDE city is in a county which borders on the youth's county of residence, while a "state level" match is one where the price is for a city within the same state but is not a "perfect" or "border" match); if there is no city in the STRIDE data that is also in the youth's state of residence, then the price from the STRIDE city nearest the youth's county of residence is used as the marijuana price (the quality of this match is also defined at two levels - a "nearby" match is defined as one where the price is from a city within 50 miles of the youth's county of residence), while the "poorest" match is defined for cities which are more than 50 miles from and not in the state as the youth's county of residence. Estimates using subsamples of the data based on the quality of the price match, as well as estimates for the full sample, are presented below.

A second problem with the marijuana price data is that the data are available only for the fourth quarter of 1988 and the fourth quarter of 1989 . Price data for 1982 were not obtained in the data graciously made available by Paul Taubman for this research. Thus, all equations estimated which include marijuana prices use only the 1989 crosssection (or a subsample of this survey). A simple average of the 1988 and 1989 fourth quarter prices is used as the price of marijuana for the 1989 sample (surveyed in the spring of 1989).

\footnotetext{
In addition to the estimates presented below, additional estimates were obtained for more rescricted subsamples. In general, the estimates obtained from the more restricted, much smaller samples are similar to, albeit less statisrically significant than, the estimates presented here. These estimates are available on request. Also, due to the problems in assigning appropriate local marijuana prices, these prices are not deflated by the local cost-of-living index from the ACCRA data.

- All equations were also estimated using the 1988 price or the 1989 price as the price of marijuana. The results for these variables are comparable to those presented below and are available on request.
} 
A third problem with the marijuana price data is that they are reported as a range of values rather than as a single value. For example, the national average price of commercial grade marijuana at the wholesale level in the fourth quarter of 1988 is reported as $\$ 350-\$ 1,800$. While the ranges reported for the city specific prices are somewhat narrower, there is still a large range of prices reported for wholesale and retail commercial grade and sinsemilla marijuana in each city. The results presented in this paper use the midpoint of the range reported in the STRIDE data as the price of marijuana. $^{10}$

There is clearly substantial measurement error in the marijuana money price data. For example, one would expect that the alternative price measures should be relatively highly correlated, since each is likely to be related to drug enforcement efforts and other factors which would be expected to influence price. It is somewhat comforting to note that the correlation between the wholesale prices for commercial grade and sinsemilla marijuana is 0.45 , while the correlation between the wholesale and retail prices of commercial grade marijuana is also 0.45 . More disturbing is the observation that the correlation between the retail prices of the two types of marijuana is only 0.15 and that the correlation between the wholesale and retail prices of sinsemilla is -0.002 ." This suggests that the retail price of sinsemilla may be measured with the most error, since it is neither correlated with its own wholesale price nor with the retail price of commercial

\footnotetext{
${ }^{10}$ In addition to using the midpoint of the range of prices reported, alternative estimates were obtained using the minimum and maximum values for the range of prices. The results obtained using these alternative measures were generally similar to those presented below and are available upon request.

1"These correlation coefficients were obtained based on the prices assigned to the full sample, as described above. Similar values are obtained in the subsamples as well as in the raw data.
} 
grade marijuana as would be expected. While the money price of marijuana is measured with substantial error, the other measure of the full price of marijuana, the decriminalization indicator, is more reliable. Thus, any conclusions made below on the substitutability or complementarity of marijuana and alcohol among youths will not be based solely on a variable measured with error. Finally, reliable estimates of other illegal drug prices were unavailable. As a result, a potential omitted variables bias is introduced, which may be particularly problematic if the prices of other illegal drugs are correlated with the marijuana prices which are included. This is likely to be the case since the prices of other illegal drugs will be influenced by the same enforcement and other factors which affect the price of marijuana. Again, this is less likely to be a problem with the estimates obtained for the decriminalization indicator, since all other illegal drugs are criminalized in all states. ${ }^{12}$

Several independent variables were constructed from the wealth of socioeconomic and demographic information collected in the surveys. These include indicators of sex, race (black, and other), and work status (part-time and full-time), as well as the youth's age. Real weekly income is created by deflating the youth's nominal weekly income data collected in the survey by the local cost-of-living index and the national CPI. In addition, some of the specifications presented below include indicators of religious participation (infrequent and frequent attendance at religious services). It is thought that those who are more committed to their religion (as measured by more frequent attendance) will be

\footnotetext{
${ }^{12}$ Future research will make use of variables measuring the mandatory minimum penalties associated with both the possession and manufacture/distribution of all illegal drugs, as well as illegal drug prices constructed from the STRIDE data.
} 
less likely to drink heavily. Finally, in all equations estimated for the combined 1982 and 1989 sample, a dichotomous indicator equal to 1 for youths surveyed in 1982 is included.

C. Results

Ordered probit estimates of the frequency of alcohol consumption in the past year and in the past thirty days are presented in columns 1 and 2, respectively, of Tables 2 and 3 below. Dichotomous probit estimates for the probability of at least one heavy drinking incident in the past two weeks are presented in column 3 of these tables. Panel A of Table 2 presents estimates using the combined 1982 and 1989 sample for equations which exclude the money price of marijuana. Panel A of Table 3 presents estimates using the 1989 sample only of equations which include each of the four alternative marijuana money prices. In addition, Panel B of Table 4 contains estimates for a subsample of the 1989 sample based on the quality of the marijuana price match. ${ }^{13}$ Panel B of Table 2, for comparison purposes, contains estimates of equations excluding the money price of marijuana for the 1989 sample only. Each table presents the coefficient estimates for beer prices, the minimum legal drinking age, the dichotomous indicator of a lower border drinking age (pooled sample only), the dichotomous indicator for marijuana

\footnotetext{
13 The restricted sample is limited to observarions where the marjuana price assigned to the youth is for a city from the STRIDE data which is in the same state in which the youth resides. In most cases, this city is relatively close to the youth's county of residence, implying that the price in that ciry should be a reasonably good measure of the price the youth faces for marijuana. Observations where prices are from a city in the STRIDE data which is not in the youth's state of residence are dropped in the restricted sample. Even if the youth lives near the ciry from which the price is taken, the assigned price may not be a good measure of the price the youth faces if the drug enforcement activities in his/her state are quite different from those in the state from which the price is taken.
} 
decriminalization, and, where included, the money price of marijuana. ${ }^{14}$

In nearly every equation estimated, the coefficient of the real beer price is negative and statistically significant at the ten percent significance level, with many significant at the one percent level. The only exceptions to this are some of the equations using the 1989 sample which include the wholesale price of sinsemilla as the price of marijuana. In general, these results support the findings of the substantial economics literature describing the negative relationship between youth alcohol consumption and the prices of alcoholic beverages (for example, see the summary by Grossman, Chaloupka, Saffer, and Laixuthai, forthcoming).

Furthermore, these estimates indicate that the effects of price on consumption are not limited to infrequent drinkers, but that fairly frequent and frequent drinkers as well as heavy drinking among youths falls as price rises. This is clearly shown by the negative significant coefficients estimated for the beer price in the probability of heavy drinking equations. The coefficients obtained from the ordered probit estimation for the frequency of drinking in the past year and drinking in the past month are somewhat more difficult to interpret. The negative and significant estimates obtained for price indicate that an increase in the beer price will lead to a reduction in the number of youths in the most frequent drinking categories (40 or more drinking occasions in the past year or ten or more drinking occasion in the past month). Similarly, these estimates imply that the number of youths who do not drink would rise in response to an increase in beer prices.

\footnotetext{
14 All equations also include an intercept, the indicators of gender, race, work status, and religious participation, as well as the youth's real weekly income and age, as described above. The pooled sample also includes the dichotomous year indicator for 1982. These results are available upon request.
} 
However, no clear conclusions for the number of infrequent or fairly frequent drinkers can be drawn directly from the estimates (for example, while some fairly frequent drinkers will reduce consumption in response to the price increase, some formerly frequent drinkers may end up as fairly frequent drinkers, leaving the net effect unclear). The results from the policy simulations presented in the next section will shed some light on the impact of prices and other variables on these groups.

Similarly, the impact of higher minimum legal drinking ages on both the frequency of alcohol consumption and the probability of heavy drinking is also negative and significant in most of the estimated equations. In addition, the indicator for youths who live near a state with a lower legal age than that in their own state is positive and highly significant as expected. These estimates imply that increases in the minimum legal drinking age increase the "cost" to youths of obtaining alcohol and, consequently, lead to reductions in both the frequency of youth alcohol consumption and the probability of heavy drinking among youths. However, states which increase their own minimum legal drinking ages above those in nearby states (as happened throughout the late 1970's and early 1980's) can expect at least some young residents to leave the state to obtain alcohol. Thus, while overall youth alcohol consumption may be lower as the result of higher drinking ages, drinking and driving by youths may actually rise when differences in own and nearby state drinking ages increase. This potential consequence of higher drinking ages in some states was eliminated when all states raised their legal ages to 21 years to comply with the Uniform Drinking Age Act. This possibility will be examined below. 
equal to zero otherwise. ${ }^{18}$ The independent variables included in the estimation of this equation are identical to those included in the alcohol demand equations described above,

A pooled time-series of state cross-sections for the 48 contiguous states of the U.S. covering the years from 1975 through 1988 is used to examine the effects of alcohol and marijuana prices on the probability of a fatal youth motor vehicle accident.

Motor vehicle accident fatality rates are the most commonly used empirical measure of intoxicated driving available. While not all motor vehicle fatalities are the results of drunk and/or "drugged" driving, there is a strong correlation between the two measures. During this time period, the National Highway Traffic Safety Administration (NHTSA) estimates that alcohol was involved in over half of these deaths, and that this percentage is much higher for people under the age of 25 . Owens, et al., (1983), and Johnson and White (1989) present evidence that marijuana use could also play a role in at least some motor vehicle accident fatalities.

Three alternative fatality rates, based on the information contained in the NHTSA's Fatal Accident Reporting System (FARS) database are constructed for 18 through 20 year olds, and for 15 through 24 year olds. The first is the total fatality rate for the two age categories. While this certainly includes non-intoxicated fatalities, it is a useful measure for examining the overall impacts of policies related to drug and alcohol use. The two remaining fatality measures are limited to drivers only and are constructed in an attempt

\footnotetext{
${ }^{10}$ The survey includes continuous information on the number of motor vehicle accidents, with an upper limit of four or more accidents. However, almost no youth report more than one accident, so non-zero responses are collapsed into a single category indicating at least one accident in the past year.
} 
(1984), for example). ${ }^{15}$ Instead, this finding implies that high school seniors, many of whom are likely to have initiated their alcohol and drug use several years earlier, treat alcohol and marijuana as substitutes for one another.

This conclusion is generally supported by the coefficients obtained for the alternative measures of marijuana prices. In both the full and restricted 1989 samples, positive and highly significant coefficients are obtained for the wholesale price of marijuana (both commercial grade and sinsemilla). The findings for retail marijuana prices are mixed. The coefficients for the retail price of commercial grade marijuana are always positive and generally significant, except in the frequency of drinking in the past year equations where they are positive but insignificant. Retail sinsemilla prices, however, are estimated to have a negative and generally significant impact on alcohol consumption in both the full and restricted sample. The findings for both wholesale prices and for the retail price of commercial grade marijuana can be viewed as more reliable for two reasons: first, the retail price of sinsemilla appears to be subject to the most measurement error, as discussed above; and, second, sinsemilla is a much higher priced strain of marijuana which constitutes only a small part of the market making it less likely to be used by youths. ${ }^{18}$

\footnotetext{
${ }^{15}$ Future research will use some of the longitudinal data collected as part of the Monitoring the Future project to examine the gateway hypothesis.

${ }^{10}$ Kleinan (1992) describes the evolution of the marijuana market over time, noting that most of the U.S. market was supplied from foreign sources and that most foreign marijuana is commercial grade. He goes on to note that successful interdiction efforts have led to a much larger domestic supply and that, combined with improvements in cultivation, this has led to an increase in the potency of marijuana (both commercial and sinsemilla).
} 


\section{Policy Simulations}

As mentioned above, it is difficult to use the ordered probit coefficients to interpret the effects of changes in the variables of interest on the frequency of drinking. While the coefficients themselves provide some information, particularly for the top (frequent drinkers) and bottom (abstainers) categories, the marginal effect of the variable on each category is more useful. Table 4 presents simulation results which use these marginal effects to evaluate the impact of changes in various policies on the frequency of youth drinking and the probability of heavy drinking by youths. ${ }^{17}$ Each of the cells in Table 4 indicates the percentage change in the number of respondents predicted to fall into each of the categories as a result of the change in policy being simulated (recall that the original distributions are presented in Table 1). Panel A of Table 4 contains the simulation results for the pooled 1982 and 1989 sample, while Panel B contains those for the 1989 sample only. Panels B.1, B.2, B.3, B.4, and B.5 present the results for no marijuana price, the wholesale commercial grade marijuana price, the wholesale sinsemilla price, the retail commercial grade marijuana price, and the retail sinsemilla price, respectively. All simulation results presented are based on the coefficients from the models estimated using the full samples.

\footnotetext{
${ }^{17} 17$ The underlying model is assumed to be $Y^{\prime}=\mathbf{B} X+\epsilon$, where $Y$ is alcohol consumption, $X$ contains determinants of consumption, $B$ are coefficients, and $\epsilon$ is an error. However, $Y$ is not observed. What is observed is $Y=0,1,2$, and 3 , when $Y \leq 0,0 \leq Y \leq \mu_{1}, \mu_{1} \leq Y \leq \mu_{2}$, and $\mu_{2} \leq Y$, respectively. The probabilities of each outcome are:

Prob $[Y=0]=1-\Phi(\mathbf{B X})$

Prob $[Y=1]=\Phi\left(\mu_{1},-B^{\prime} X\right)-\Phi\left(-B^{\prime} \mathbf{X}\right)$

$\operatorname{Prob}[Y=2]=\Phi\left(\mu_{2}-B^{\prime} X\right)-\Phi\left(\mu_{1}-B^{\prime} X\right)$

$\operatorname{Prob}[Y=3]=1 \cdot \Phi\left(\mu_{2}-B^{\prime} X\right)$

where $\Phi$ is the cumulative standard nomal distribution (from Greene, 1990). Simulations are conducted by changing the appropriate independent variable to reflect the policy under consideration and recomputing the probabilities based on the estimated coefficients.
} 
Four alternative policy simulations are presented. The first increases the federal excise tax on beer to offset the effects of inflation since 1951 (this amounts to a 17.1 percent increase in the average price of beer in the pooled sample and about an 18 percent increase in the 1989 sample, assuming that the tax increase is fully passed on to consumers). The second simulates the impact of recriminalization of marijuana in every state while the third considers marijuana decriminalization in all states. Finally, the fourth examines the impact of a reduction in the price of marijuana comparable to the increase in the price of beer associated with the tax increase described above (that is, the price of marijuana is assumed to fall by 18 percent). This is done to provide some comparison between the relative responsiveness of young drinkers to changes in beer prices and marijuana prices.

As the ordered probit coefficients indicated, an increase in the beer tax leads to significant increases in the number of abstainers while the number of frequent drinkers or heavy drinkers falls sharply. For example, in the pooled sample, increasing the beer tax with inflation since 1951 would raise the numbers of abstainers in the past year and in the past month by 8.42 percent and 4.35 percent, respectively, while reducing the comparable numbers of frequent drinkers by 7.49 percent and 6.57 percent. The number of fairly frequent drinkers in either the past year or past month also falls as a result of this policy. However, the number of infrequent drinkers in the past year rises by 2.15 percent while the number of infrequent drinkers in the past month falls slightly. Finally, the probability of a heavy drinking episode falls by 2.28 percent in response to the large price increase induced by the tax change. This confirms the findings of other studies 
(Grossman, Coate and Arluck, (1987) and Coate and Grossman (1988), for example) which find that the impact of increases in alcoholic beverage excise taxes are not limited to infrequent drinkers, but that frequent drinkers are very responsive to price changes as well.

Simulating the effects of uniform criminalization of marijuana versus uniform decriminalization of marijuana proves quite interesting. As indicated by the estimated coefficients, there is strong evidence that, at least for high school seniors, marijuana and alcohol could be considered substitutes. Thus, moving from a situation where marijuana is criminalized everywhere, implying substantial penalties for possession and/or use, to one where marijuana is decriminalized everywhere, significantly reducing the expected costs of marijuana use, leads to substitution away from alcohol. Based on the results from the pooled sample, for example, this change in policy would increase the number of abstainers in the past year by nearly 12 percent, while reducing the number of frequent drinkers in the past year by almost 11 percent. The number of infrequent drinkers would rise by about three percent, while the number of fairly frequent drinkers would ball by almost four percent. Likewise, the probability of a heavy drinking episode would fall sharply, by approximately 11.55 percent, in response to this policy shift.

Finally, as shown by most of the estimated marijuana price coefficients, a reduction in the price of marijuana reduces alcohol consumption, again implying that youths are substituting the two substances. For example, looking at the changes in drinking in the past month induced by changes in beer prices and in the retail price of commercial grade marijuana (perhaps most likely to represent the price youths face for marijuana), one finds 
that an 18 percent increase in the beer price would reduce the number of frequent drinkers by 6.28 percent while the comparable marijuana price reduction would reduce the number of frequent drinkers by 2.84 percent. Similarly the number of abstainers in the past month is predicted to rise by 5.04 percent and 2.24 percent for the changes in beer prices and marijuana prices, respectively. These estimates suggest that the responsiveness of youth drinking to a decline in marijuana prices is almost half that resulting from an increase in beer prices. Other models predict an even larger cross price effect, providing strong evidence of the substitutability between alcohol and marijuana among youths. The next section considers the effects of this substitution on one of these consequences of substance use among youths, driving under the influence of alcohol and/or drugs.

\section{Driving Under the Influence of Drugs and/or Alcohol}

\section{A. Analytical Framework}

The underlying model which provides the basis for the empirical analysis of youth driving under the influence consists of several equations. The first is a technical relationship in which the probability that a youth is involved in an accident (fatal accident), $\pi$, is positively related to his/her intoxication while driving, as well as to a vector of additional variables $(H)$ reflecting roadway, traffic, and motor vehicle conditions:

$$
\pi=\pi(\mathrm{l}, \mathrm{H})
$$


As described in equation (2) above, intoxication is produced by consuming alcohol marijuana, and/or other drugs. Substituting equation (2) into equation (6) yields a production function in which the probability of an accident (fatal accident) depends positively on the consumption of alcohol, marijuana, and other drugs:

$$
\pi=\pi(A, M, D, H)
$$

Finally, a reduced form probability of an accident (fatal accident) equation is obtained by substituting the demands for alcohol, marijuana, and other drugs equations (3), (4), and (5) above, into equation (7):

$$
\pi=\pi\left(P_{A}, P_{M}, P_{D}, P_{X_{0}} Y, Z, H\right)
$$

Two versions of equation (8) are estimated. The first uses the Monitoring the Future data to examine the probability that a youth is involved in a least one traffic accident in the previous year. In the second, the reduced form equation is aggregated over youths in each state in each year. The result is an empirically estimable equation where the probability of a fatal youth motor vehicle accident is measured by the observed youth motor vehicle accident fatality rate. Both overall and alcohol related youth fatality rates, constructed from the FARS, are examined.

It is expected that a reduction in the price of marijuana (as the result of a state decriminalizing marijuana, for example) will lead to an increase in marijuana consumption, 
which, holding alcohol consumption constant, will lead to more driving while intoxicated, and, consequently more youth accidents and fatal accidents. However, based on the youth alcohol demand equations estimated above, reductions in the price of marijuana lead to reductions in alcohol consumption as well. The reduced alcohol consumption will be accompanied by less drinking and driving and, hence, fewer alcohol related accidents and fatal accidents. Thus, the overall impact of a drop in marijuana prices on the probability of an accident (fatal accident) depends not only on the increased marijuana consumption it induces, but on the substitution away from alcohol which results. Finally, the net effect will also depend on the relative risks associated with drunk driving compared to "stoned" driving. For example, Kleiman (1992) suggests that marijuana use leads to slower, as well as impaired, driving. This would imply that the probability of an accident might not differ, but that the probability of a fatal accident would be higher when drunk than when stoned.

\section{B. Data}

To look at the impact of alcohol and marijuana prices on the probability of a nonfatal motor vehicle accident among youths, the 1982 and 1989 surveys of high school seniors described above are used. The dependent variable in these equations is a dichotomous variable equal to one if the youth reports driving during at least one motor vehicle accident in the past year (regardless of responsibility for the accident), and is 
equal to zero otherwise. ${ }^{18}$ The independent variables included in the estimation of this equation are identical to those included in the alcohol demand equations described above,

A pooled time-series of state cross-sections for the 48 contiguous states of the U.S. covering the years from 1975 through 1988 is used to examine the effects of alcohol and marijuana prices on the probability of a fatal youth motor vehicle accident.

Motor vehicle accident fatality rates are the most commonly used empirical measure of intoxicated driving available. While not all motor vehicle fatalities are the results of drunk and/or "drugged" driving, there is a strong correlation between the two measures. During this time period, the National Highway Traffic Safety Administration (NHTSA) estimates that alcohol was involved in over half of these deaths, and that this percentage is much higher for people under the age of 25 . Owens, et al., (1983), and Johnson and White (1989) present evidence that marijuana use could also play a role in at least some motor vehicle accident fatalities.

Three alternative fatality rates, based on the information contained in the NHTSA's Fatal Accident Reporting System (FARS) database are constructed for 18 through 20 year olds, and for 15 through 24 year olds. The first is the total fatality rate for the two age categories. While this certainly includes non-intoxicated fatalities, it is a useful measure for examining the overall impacts of policies related to drug and alcohol use. The two remaining fatality measures are limited to drivers only and are constructed in an attempt

\footnotetext{
${ }^{10}$ The survey includes continuous information on the number of motor vehicle accidents, with an upper limit of four or more accidents. However, almost no youth report more than one accident, so non-zero responses are collapsed into a single category indicating at least one accident in the past year.
} 
to focus on intoxicated drivers. The first driver specific fatality rate is limited to deaths which occur between 12:00 a.m. and 3:59 a.m. and is called the night driver fatality rate. The NHTSA estimates that 75-90 percent of these drivers had been drinking prior to their deaths. It is suspected that a large number of these drivers may also have been using illegal drugs (either with or without alcohol). The final fatality rate is an estimated alcohol involved driver fatality rate constructed from the blood alcohol concentration information contained in the FARS." This fatality rate focuses on alcohol use and allows for a clearer examination of the potential substitution between alcohol and marijuana.

Each fatality rate is computed as the relevant number of motor vehicle accident deaths divided by the relevant state population. The fatality equation is specified as a logistic equation. The logistic functional form is ideal since it constrains the fatality rate to lie botween zero and one. The logistic specification is obtained by transforming the fatality rate to $\ln [F /(1-F)]$, where $F$ is the fatality rate and $\ln$ is the natural logarithm. Maddala (1983) shows that weighted least squares should bo used with this logistic transformation. The weight is $[n F(1-F)]^{k}$, where $n$ is the relevant state population.

Three variables are included as measures of the full price of alcoholic beverages. The first is the price of alcohol, measured by the excise tax rate on beer. Excise tax data are the most reliable price data available at the state level during this time period. Beer tax data were chosen since beer is the most popular alcoholic beverage in the U.S. and because meaningful wine and distilled spirits taxes are only available for states which

\footnotetext{
10 See Chaloupka, Saffer, and Grossman, (1993), for more detailed information on the construction of the alcohol involved driver fatality rate. BAC data is available since 1977 in the FARS. As a result, the sample consists of the 48 contiguous states of the U.S. from 1977 through 1988 in all equations estimated using the alcohol involved driver fatality rate as the dependent variable.
} 
permit the sale of all alcoholic beverages in licensed establishments. The beer tax variable is defined as the sum of the Federal and state excise tax rates on a case of 2412 ounce containers of beer and is deflated by the national CPI (1982-1984 base year). The Federal tax had been fixed at 64 cents from 1951 until 1991, when it was doubled as part of a deficit reduction package. If a state raised its tax during the year, the tax is computed as the weighted average of the rates in effect throughout the year. State excise tax rates were taken from the U.S. Brewers Association's annual Brewers Almanac.

The second measure, reflecting availability of alcohol, is the minimum legal drinking age for low alcohol content beer. The final measure of the full price of alcohol, again reflecting availability, is the percentage of the state population residing in counties which prohibit the sale of alcohol, or "dry" counties. These data were obtained from the Brewers Almanac.

The full price of marijuana is captured by an indicator for states which have decriminalized marijuana. Decriminalization of marijuana eliminates possible imprisonment for most first offense possession violations. Oregon, in 1973, was the first state to decriminalize marijuana. By 1978, 10 other states had followed, substantially reducing the penalties associated with marijuana possession. Decriminalization, by lowering the penalties associated with marijuana use, is expected to significantly increase marijuana consumption. In addition, if alcohol and marijuana are substitutes, then decriminalization is expected to reduce alcohol consumption. The net effect of decriminalization on motor vehicle accident fatalities, however, is unclear.

Four other alcohol related variables are included in all equations as measures of 
unobserved exogenous sentiment towards alcohol. For example, anti-alcohol sentiment should be relatively widespread in states in which religious groups opposing alcohol are prevalent or in states in which a higher than average fraction of the population reside in counties prohibiting the sale of alcohol. Thus, variables are defined for the percentages of the state population who are Mormons, Southern Baptists, other Protestants, and Catholics. These data were available from the National Council of Churches for 1971 and 1980 only. Estimates for 1975 through 1988 were computed by logarithmic trend.

Real per capita personal income is also included in all equations. Income should be positively related to the demand for health, as well as to the quality and condition of motor vehicles, and may be positively related to the demand for alcohol and marijuana. Thus, the predicted effect of income on fatality rates is ambiguous.

Additionally, five variables are used to control for the probability of a fatal motor vehicle accident. They are the percentage of highway traffic exceeding 65 miles per hour, the number of vehicle miles traveled in 100,000's of miles per licensed driver, the fraction of licensed drivers ages 24 years and under, a dichotomous indicator for states requiring annual safety inspections of all motor vehicles, and a dichotomous indicator of a mandatory seat belt use law. The first three of these variables were computed using data from the Federal Highway Administration's Highway Statistics, and unpublished data provided by the FHA. The safety inspection indicator was taken from the American Automobile Association's Digest of Motor Laws. Finally, information on mandatory seat belt use laws was obtained from communications with the NHTSA.

Vehicle miles per driver reflect motor vehicle use and traffic density and should be 
positively related to fatality rates. According to Peltzman (1975), because young drivers have a higher demand for risky driving, they are more likely to have an accident than older drivers. Thus, an increase in the fraction of young drivers should have a positive effect on fatality rates. Similarly, vehicle speed should also have a positive effect on fatality rates, with deviation from the average speed also having a positive effect. Thus, an increase in the percentage of drivers exceeding $65 \mathrm{mph}$ on highways should lead to higher fatality rates. Likewise, mandatory safety inspections should result in safer vehicles and, as a result, lower fatal accident rates. Lastly, increased seat belt use resulting from the mandatory seat belt use laws should reduce the probability of a fatal accident.

Finally, temporal variation in unmeasured variables and other time trends are modeled by a set of dichotomous variables for each of the years from 1975 through 1987 (1977 through 1987 for the alcohol involved driver rates).

\section{Results}

Dichotomous probit estimates of the probability of a non-fatal traffic accident, using the data from the 1982 and 1989 Monitoring the Future surveys are presented in Table 5. Columns 1 and 2 of Table 5 contain estimates of equations excluding marijuana money prices for the pooled sample and for the 1989 sample, respectively. Columns 3 through 6 of Table 5 present the estimates for the 1989 sample only from equations which include alternative measures of the money price of marijuana. Panel A of Table 5 presents the results for the full samples, as defined above, while Panel B contains estimates for the smaller sample based on more exact marijuana money price matches. 
Only the coefficients for the beer and marijuana price variables, the legal drinking age measures, and the decriminalization indicator from equations which exclude the religion variables are shown. All equations, however, include the same set of other independent variables described above. ${ }^{20}$

Weighted least squares estimates of youth motor vehicle accident fatality rates are contained in Table 6. Panel A of Table 6 contains the estimates of the beer tax, drinking age, and decriminalization coefficients for the 15 through 24 year oid fatality rates, with comparable estimates for 18 through 20 year olds presented in Panel B. Estimates for the 18 through 20 year old sample are presented to highlight the impact of the minimum legal drinking age which most affects this age group. Column 1 of Table 6 presents the results for the total youth motor vehicle accident fatality rates, while columns 2 and 3 contain estimates for the night driver and alcohol involved driver rates, respectively.

Beer prices are found to have a negative and generally significant impact on both the probability of a non-fatal motor vehicle accident and a fatal motor vehicle accident. This is true for each of the various samples constructed from the surveys of high school seniors as well as for each of the alternative age-specific fatality rates constructed from the FARS data. The finding that youth motor vehicle accident fatality rates are inversely related to the price of alcoholic beverages is consistent with a number of other studies which have addressed this issue (see Saffer and Grossman, 1987, and Chaloupka, Saffer, and Grossman, 1993, for example). However, while expected, this is the first empirical

\footnotetext{
20 This set includes an intercept, dichotomous indicators of gender, race, employment status, and religious participation, and the youth's real weekly income and age. The pooled sample also includes a dichotomous indicator for 1982 . Estimates for these variables are available upon request.
} 
evidence indicating that non-fatal youth motor accidents are also inversely related to prices.

Drinking ages, however, do not appear to have much of an impact on non-fatal youth motor vehicle accidents, based on the results presented in Table 5 . This was a somewhat surprising finding given the extensive literature and confirmed by the results shown in Table 6, which finds that higher minimum legal drinking ages lead to lower youth motor vehicle accident fatality rates, particularly among 18 through 20 year olds. For the samples based on the 1989 survey, this finding may be in part due to the fact that almost every state's drinking age was 21 at this time. However, that doesn't explain the unexpected positive and significant effect estimated for the pooled sample.

The estimated coefficients on the decriminalization indicator are negative and highly significant in every equation, with the exception of those for the probability of a non-fatal accident which include the retail price of commercial grade marijuana, where they are negative but insignificant at conventional levels. Similarly, marijuana prices are found to have a positive and generally significant impact on the probability a non-fatal motor vehicle accident.

\section{Policy Simulations}

To compare the impact of various alcohol and marijuana related policies on driving under the influence by youths, policy simulations comparable to those described above were conducted. The results from these simulations are presented in Tables 7 and 8. Table 7 contains the predicted changes in the number of youths involved in at least one 
non-fatal traffic accident in response to the four policy changes. Column 1 of Table 7 presents the policy simulations for the pooled sample, while Column 2 presents those based on the 1989 survey only excluding the money price of marijuana. Columns 3-6 contain the results when the four alternative money prices of marijuana are included in the models for the 1989 sample (the wholesale and retail prices of commercial grade marijuana ( 3 and 5 respectively) and sinsemilla ( 4 and 6 respectively)). All predictions contained in Table 7 are based on the coefficients estimated for the full samples. Table 8 contains the estimated percentage change in the youth motor vehicle accident fatality rate associated with the change in policy being simulated as well as the estimate change in the number of fatalities in each category in the final year of the sample (1988) resulting from the policy change.

Large increases in the excise tax on beer will lead to substantial reductions in both non-fatal and fatal motor vehicle accidents among youths. The approximately 17 percent increase in the price of beer induced when the federal tax is increased to offset the effects of inflation since 1951 leads to an almost six percent reduction in the probability of a non-fatal accident in the pooled sample of high school seniors. Similarly, maintaining the real value of the beer tax at its 1951 level during the period from 1975 through 1988 would have reduced fatal motor vehicle accidents by over 16 percent among 15 through 24 year olds and nearly 20 percent among 18 to 20 year olds. In 1988 , these estimates imply that 2,288 lives would have been saved in the 15 through 24 year old group.

A reduction in marijuana prices, which is expected to increase marijuana consumption but reduce drinking based on the results described above, leads to a 
significant drop in the probability of a non-fatal motor vehicle accident among high school seniors. The estimated reductions in this probability for the 18 percent fall in each of the four marijuana prices used in this paper range from -2.25 percent up to -7.25 percent. This implies that the net effect of the substitution towards marijuana on the probability of an accident induced by the drop in the price of marijuana is negative. That is, the increase in the probability of a non-fatal accident resulting from greater marijuana use is more than offset by the drop in this probability resulting from less drinking and driving and, perhaps, less use of other intoxicating substances and driving.

This conclusion is further supported by the estimated effects of marijuana decriminalization on the probabilities of both non-fatal and fatal motor vehicle accidents among youths. Going from a nationwide policy criminalizing marijuana to one where marijuana is decriminalized everywhere leads to about a 7.5 percent drop in the probability of a non-fatal accident in the pooled sample of high school seniors. Somewhat larger reductions are estimated in most of the specifications for the 1989 sample only. Similarly, this change in policy is predicted to reduced the fatal accident rate by almost 5.5 percent among 15 through 24 year olds and just over six percent among 18 to 20 year olds. In 1988, an estimated 224 fewer youth and young adult lives (ages 15-24) were lost in fatal traffic accidents in the states which had decriminalized marijuana. Decriminalization in all other states, based on these estimates, would have saved an additional 549 lives in this age group. Again, this is expected to be the result of substitution towards marijuana and away from alcohol and other intoxicating substances in the states where the penalties associated with marijuana use are much 
lower.

\section{N. Conclusions}

The findings on youth alcohol use suggest that successful marijuana related efforts in the "War on Drugs", which can be expected to reduce the supply of marijuana and, hence, increase its price will not only lead to less marijuana consumption, but will have the unintended consequence of raising alcohol consumption (at least among youths). This is consistent with DiNardo and Lemieux's (1992) finding that increased minimum legal drinking ages, while reducing alcohol consumption among youths, had the unintended consequence of leading to an almost one-for-one increase in marijuana use.

The findings related to youth motor vehicle accidents suggest that reductions in the full price of marijuana, resulting from either lower money prices and/or reduced legal sanctions for possession/use, lead youths to substitute away from alcoholic beverages and other intoxicating substances towards marijuana. Furthermore, the subsequent reductions in the consequences of drunken driving (non-fatal and fatal accidents) and driving under the influence of other substances more than offset the increases in the consequences of driving under the influence of marijuana. Similarly, an increase in the full price of beer, resulting, for example, from the increased taxation of alcoholic beverages and/or higher minimum legal drinking ages, lowers beer consumption and raises marijuana consumption. This would be expected to reduce drunken driving, but to raise "stoned" driving. The net effect of the beer price increase, however, is to reduce the probabilities of non-fatal and fatal youth motor vehicle accidents. 
Improved traffic outcomes may be the result of more careful and/or slower driving on the part of youths driving under the influence of marijuana as compared to those who are drinking and driving (as suggested by Kleiman), or it may be that youths are less likely to drive after consuming marijuana than they are after drinking or that marijuana consumption impairs driving less than alcohol consumption. Whether it's one of these or any other reason, the results presented here imply that the combination of higher full prices for alcoholic beverages and a lower full price for marijuana will reduce the probability of youth motor vehicle accidents, both fatal and non-fatal. This is consistent with Model's (1993 and 1991) findings, based on drug and alcohol related emergency room admissions as well as violent crime rates, that the substitution away from alcohol and other drugs towards marijuana resulting from reductions in the full price of marijuana (due to decriminalization) leads to net reductions in some of the consequences of drug and alcohol abuse.

The growing body of research in this area suggest that decriminalization, or even legalization, of marijuana only, which can be expected to reduce the full price of marijuana, would almost certainly lead to increased marijuana consumption, but at the same time reduce several of the consequences associated with all drug use, including motor vehicle accidents, other medical emergencies, and violent crime. In addition, this would free up resources for stronger enforcement efforts towards remaining illegal drugs. The appropriateness of such a policy clearly depends on the harmful consequences of alcohol, marijuana, and other illegal drug use. 


\section{Literature Cited}

Chaloupka, F.J., H. Saffer, and M. Grossman, "Alcohol-Control Policies and Motor-Vehicle Fatalities," Journal of Legal Studies, 22:1, 1993, 161-186.

Coate, D., and M. Grossman, "The Effect of Alcoholic Beverage Prices and Legal Drinking Ages on Youth Alcohol Use", Journal of Law and Economics, 31:1, 1988, 145-171.

DiNardo, J., and T. Lemieux, "Alcohol, Marijuana, and Youth: The Unintended Consequences of Government Regulation," National Bureau of Economic Research Working Paper Number 4212, 1992.

Greene, W.H., Econometric Analysis, Macmillan Publishing Company, New York, N.Y., 1990.

Grossman, M., D. Coate, and G.M. Arluck, "Price Sensitivity of Alcoholic Beverages in the United States: Youth Alcohol Consumption," in Control Issues in Alcohol Abuse Prevention: Strategies for States and Communities, edited by H.D. Holder.Greenwich, Connecticut: JAl Press, Inc., 1987.

Grossman, M., F.J. Chaloupka, H. Saffer, and A. Laixuthai, "Effects of Alcohol Price Policy on Youth: A Summary of Economic Research," Journal of Research on Adolescence, forthcoming.

Johnson, V., and H.R. White, "An Investigation of Factors Related to Intoxicating Driving Behaviors among Youth," Journal of Studies on Alcohol, 50:4, 1989, 320-330.

Johnston, L.D., P.M. O'Malley, and J.G. Bachman, National Trends in Drug Use and Related Factors Among American High School Students and Young Adults, 1975-1986, National Institute on Drug Abuse, Washington D.C., 1987.

Kandel, D.B., R.C. Kessler, and R.Z. Margulies, "Antecedents of Adolescent Initiation into Stages of Drug Use: A Developmental Analysis." In Longitudinal Research on Druq Use. edited by D.B. Kandel. New York: John Wiley and Sons, 1978.

Keiman, M.A., Against Excess: Drug Policy for Results: Alcohol, Cocaine, Heroin, Marifuana, Tobacco. New York: Basic Books, 1992.

Maddala, G.S. Limited Dependent and Qualitative Variables in Economics. Cambridge, England: Cambridge University Press, 1983.

Model, K.E., "Crime, Violence \& Drug Control Policy," Working Paper, Department of Economics, Harvard University, 1991. 
Model, K.E., "The Effect of Marijuana Decriminalization on Hospital Emergency Room Episodes: 1975-1978," Journal of the American Statistical Association, 88:423, 737-747.

O'Donnell, J.A., and R.C. Clayton, "The Stepping-Stone Hypothesis-Marijuana, Heroin, and Causality." Chemical Dependencies: Behavioral and Biomedical Issues, 4, No. 3 (1982),

Owens, S.M., A.J. McBay, and C.E. Cook, "The Use of Marijuana, Ethanol, and Other Drugs Among Drivers Killed in Single-Vehicle Crashes," Journal of Forensic Sciences, 28:2, 1983, 372-379.

Peltzman, S., "The Effects of Automobile Safety Regulations," Journal of Political Economy, 83:5, 1975.

Saffer, H., and M. Grossman, "Beer Taxes, The Legal Drinking Age and Youth Motor Vehicle Fatalities," Journal of Legal Studies, 16:2, 1987, 351-373.

Siegel, R., Intoxication: Life in Pursuit of Artificial Paradise. New York: Dutton, 1989.

Yamaguchi, K., and D.B. Kandel, "Patterns of Drug Use from Adolescence to Young Adulthood: III. Predictors of Progression." American Journal of Public Health، 74, No. 7 (July 1984), 673-681. 


\section{Table 1}

Percentage Distributions of Drinking Frequency Measures

\begin{tabular}{||l|r|r|r||}
\hline \hline Measure & $\begin{array}{c}1982 \\
\text { Sample }\end{array}$ & $\begin{array}{c}1989 \\
\text { Sample }\end{array}$ & $\begin{array}{r}\text { Pooled } \\
\text { Sample }\end{array}$ \\
\hline Drinking in Past Year & & & \\
Abstainers & $12.7 \%$ & $16.9 \%$ & $14.8 \%$ \\
Light Drinkers & $36.4 \%$ & $42.3 \%$ & $39.3 \%$ \\
Moderate Drinkers & $30.1 \%$ & $26.3 \%$ & $28.2 \%$ \\
Heavy Drinkers & $20.8 \%$ & $14.5 \%$ & $17.7 \%$ \\
\hline Drinking in Past 30 Days & & & \\
Abstainers & $30.1 \%$ & $39.8 \%$ & $34.9 \%$ \\
Light Drinkers & $41.5 \%$ & $39.5 \%$ & $40.5 \%$ \\
Moderate Drinkers & $13.0 \%$ & $9.6 \%$ & $11.3 \%$ \\
Heavy Drinkers & $15.4 \%$ & $11.1 \%$ & $13.3 \%$ \\
\hline Heavy Drinking in Past 2 Weoks & & & \\
No Heavy Drinking Episodes & $59.8 \%$ & $67.1 \%$ & $63.4 \%$ \\
At Least 1 Heavy Drinking Episode & $40.2 \%$ & $32.9 \%$ & $36.6 \%$ \\
\hline \multicolumn{2}{|l|}{} \\
\hline
\end{tabular}


Table 2

Ordered and Dichotomous Probit Estimates of Drinking Frequency

Beer Prices, Drinking Ages, and Marijuana Decriminalization

\begin{tabular}{|c|c|c|c|}
\hline Variable & $\begin{array}{l}\text { Drinking } \\
\text { in the Past } \\
\text { Year }\end{array}$ & $\begin{array}{c}\text { Drinking } \\
\text { in the Past } \\
\text { Month }\end{array}$ & $\begin{array}{c}\text { Heavy } \\
\text { Drinking in } \\
\text { Past Two } \\
\text { Weeks }\end{array}$ \\
\hline & \multicolumn{3}{|c|}{$\begin{array}{c}\text { Panel A: } \\
\text { Pooled } 1982 \\
\text { and } 1989 \\
\text { Sample }\end{array}$} \\
\hline Beer Price. & $\begin{array}{r}-11.085 \\
(-5.24)\end{array}$ & $\begin{array}{l}-8.832 \\
(-4.06)\end{array}$ & $\begin{array}{l}-4.783 \\
(-1.84)\end{array}$ \\
\hline Minimum Legal Drinking Age & $\begin{array}{l}-0.009 \\
(-1.10)\end{array}$ & $\begin{array}{l}-0.018 \\
(-2.24)\end{array}$ & $\begin{array}{l}-0.011 \\
(-1.10)\end{array}$ \\
\hline Lower Border Age & $\begin{array}{r}0.159 \\
(6.86)\end{array}$ & $\begin{array}{r}0.133 \\
(5.68)\end{array}$ & $\begin{array}{l}0.108 \\
(3.90)\end{array}$ \\
\hline Marijuana Decriminalization & $\begin{array}{l}-0.071 \\
(-4.59)\end{array}$ & $\begin{array}{l}-0.096 \\
(-6.06)\end{array}$ & $\begin{array}{l}-0.111 \\
(-5.82)\end{array}$ \\
\hline \multirow[t]{2}{*}{ Chi-Squared } & 3247.41 & 2643.43 & 2347.99 \\
\hline & \multicolumn{3}{|c|}{$\begin{array}{c}\text { Panel B: } \\
1989 \text { Sample }\end{array}$} \\
\hline Beer Price & $\begin{array}{c}-10.507 \\
(-3.78)\end{array}$ & $\begin{array}{l}-8.737 \\
(-3.04)\end{array}$ & $\begin{array}{l}-8.444 \\
(-2.45)\end{array}$ \\
\hline Minimum Legal Drinking Age & $\begin{array}{l}-0.202 \\
(-3.05)\end{array}$ & $\begin{array}{l}-0.197 \\
(-2.89)\end{array}$ & $\begin{array}{l}-0.174 \\
(-2.16)\end{array}$ \\
\hline Marijuana Decriminalization & $\begin{array}{l}-0.073 \\
(-3.22)\end{array}$ & $\begin{array}{l}-0.084 \\
(-3.60)\end{array}$ & $\begin{array}{l}-0.088 \\
(-3.16)\end{array}$ \\
\hline Chi-Squared & 1337.01 & 1092.02 & 967.77 \\
\hline
\end{tabular}

$n=25,430,12,597$ 
Table 3

Ordered and Dichotomous Probit Estimates of Drinking Frequency

1989 High School Seniors

Beer and Marijuana Prices, Drinking Ages, and Marijuana Decriminalization

\begin{tabular}{|c|c|c|c|}
\hline Variable & $\begin{array}{l}\text { Drinking } \\
\text { in the Past } \\
\text { Year }\end{array}$ & $\begin{array}{c}\text { Drinking } \\
\text { in the Past } \\
\text { Month }\end{array}$ & $\begin{array}{c}\text { Heavy } \\
\text { Drinking in } \\
\text { Past Two } \\
\text { Weeks }\end{array}$ \\
\hline & \multicolumn{3}{|c|}{$\begin{array}{l}\text { Panel A: } \\
\text { Full Sample }\end{array}$} \\
\hline Beer Price & $\begin{array}{l}-8.281 \\
(-2.95)\end{array}$ & $\begin{array}{l}-6.622 \\
(-2.28)\end{array}$ & $\begin{array}{l}-5.635 \\
(-1.62)\end{array}$ \\
\hline Minimum Legal Drinking Age & $\begin{array}{l}-0.152 \\
(-2.28)\end{array}$ & $\begin{array}{l}-0.152 \\
(-2.20)\end{array}$ & $\begin{array}{l}-0.117 \\
(-1.43)\end{array}$ \\
\hline Marijuana Decriminalization & $\begin{array}{l}-0.052 \\
(-2.29)\end{array}$ & $\begin{array}{l}-0.065 \\
(-2.74)\end{array}$ & $\begin{array}{l}-0.064 \\
(-2.27)\end{array}$ \\
\hline $\begin{array}{l}\text { Wholesale Commercial Grade } \\
\text { Marijuana Price }\end{array}$ & $\begin{array}{c}0.0003 \\
(5.83)\end{array}$ & $\begin{array}{c}0.0002 \\
(5.25)\end{array}$ & $\begin{array}{l}0.0003 \\
(5.59)\end{array}$ \\
\hline \multirow[t]{2}{*}{ Chi-Squared } & 1371.03 & 1119.59 & 999.07 \\
\hline & \multicolumn{3}{|c|}{$\begin{array}{l}\text { Panel B: } \\
\text { Restricted } \\
\text { Sample }\end{array}$} \\
\hline Beer Price & $\begin{array}{l}-5.307 \\
(-1.60)\end{array}$ & $\begin{array}{l}-7.292 \\
(-2.12)\end{array}$ & $\begin{array}{l}-8.679 \\
(-2.12)\end{array}$ \\
\hline Minimum Legal Drinking Age & $\begin{array}{l}-0.064 \\
(-0.91)\end{array}$ & $\begin{array}{l}-0.131 \\
(-1.80)\end{array}$ & $\begin{array}{l}-0.101 \\
(-1.16)\end{array}$ \\
\hline Marijuana Decriminalization & $\begin{array}{l}-0.012 \\
(-0.34)\end{array}$ & $\begin{array}{l}-0.091 \\
(-2.51)\end{array}$ & $\begin{array}{l}-0.119 \\
(-2.74)\end{array}$ \\
\hline $\begin{array}{l}\text { Wholesale Commercial Grade } \\
\text { Marijuana Price }\end{array}$ & $\begin{array}{c}0.0002 \\
(3.41)\end{array}$ & $\begin{array}{c}0.0002 \\
(4.02)\end{array}$ & $\begin{array}{c}0.0004 \\
(5.12)\end{array}$ \\
\hline Chi-Squared & 705.17 & 586.77 & 583.54 \\
\hline
\end{tabular}

$n=12,597 ; 6,272$ 
Table 3 (continued)

Beer and Marijuana Prices, Drinking Ages, and Marijuana Decriminalization

\begin{tabular}{|c|c|c|c|}
\hline Variable & $\begin{array}{c}\text { Drinking } \\
\text { in the Past } \\
\text { Year }\end{array}$ & $\begin{array}{c}\text { Drinking } \\
\text { in the Past } \\
\text { Month }\end{array}$ & $\begin{array}{c}\text { Heavy } \\
\text { Drinking in } \\
\text { Past Two } \\
\text { Weeks }\end{array}$ \\
\hline & \multicolumn{3}{|c|}{$\begin{array}{c}\text { Panel A: } \\
\text { Full Sample }\end{array}$} \\
\hline Beer Price & $\begin{array}{l}-5.022 \\
(-1.61)\end{array}$ & $\begin{array}{l}-1.578 \\
(-0.49)\end{array}$ & $\begin{array}{r}1.360 \\
(0.35)\end{array}$ \\
\hline Minimum Legal Drinking Age & $\begin{array}{l}-0.203 \\
(-3.07)\end{array}$ & $\begin{array}{l}-0.201 \\
(-2.94)\end{array}$ & $\begin{array}{l}-0.180 \\
(-2.22)\end{array}$ \\
\hline Marijuana Decriminalization & $\begin{array}{l}-0.095 \\
(-4.07)\end{array}$ & $\begin{array}{l}-0.113 \\
(-4.70)\end{array}$ & $\begin{array}{l}-0.129 \\
(-4.47)\end{array}$ \\
\hline $\begin{array}{l}\text { Wholesale Sinsemilla Marijuana } \\
\text { Price }\end{array}$ & $\begin{array}{l}0.0001 \\
(3.91)\end{array}$ & $\begin{array}{l}0.0001 \\
(4.92)\end{array}$ & $\begin{array}{c}0.0002 \\
(5.55)\end{array}$ \\
\hline \multirow[t]{2}{*}{ Chi-Squared } & 1352.28 & 1116.21 & 998.50 \\
\hline & \multicolumn{3}{|c|}{$\begin{array}{c}\text { Panel B: } \\
\text { Restricted } \\
\text { Sample }\end{array}$} \\
\hline Beer Price & $\begin{array}{l}0.979 \\
(0.25)\end{array}$ & $\begin{array}{l}-0.078 \\
(-0.02)\end{array}$ & $\begin{array}{l}1.204 \\
(0.25)\end{array}$ \\
\hline Minimum Legal Drinking Age & $\begin{array}{l}-0.104 \\
(-1.48)\end{array}$ & $\begin{array}{l}-0.180 \\
(-2.47)\end{array}$ & $\begin{array}{l}-0.172 \\
(-1.98)\end{array}$ \\
\hline Marijuana Decriminalization & $\begin{array}{l}-0.051 \\
(-1.46)\end{array}$ & $\begin{array}{l}-0.138 \\
(-3.81)\end{array}$ & $\begin{array}{l}-0.187 \\
(-4.29)\end{array}$ \\
\hline $\begin{array}{l}\text { Wholesale Sinsemilla Marijuana } \\
\text { Price }\end{array}$ & $\begin{array}{l}0.0001 \\
(3.48)\end{array}$ & $\begin{array}{l}0.0001 \\
(3.86)\end{array}$ & $\begin{array}{c}0.0002 \\
(4.41)\end{array}$ \\
\hline Chi-Squared & 705.61 & 585.52 & 576.75 \\
\hline
\end{tabular}

$n=12,597 ; 6,272$ 
Table 3 (continued)

Beer and Marijuana Prices, Drinking Ages, and Marijuana Decriminalization

\begin{tabular}{|lccc||}
\hline Variable & $\begin{array}{c}\text { Drinking } \\
\text { in the Past } \\
\text { Year }\end{array}$ & $\begin{array}{c}\text { Drinking } \\
\text { in the Past } \\
\text { Month }\end{array}$ & $\begin{array}{c}\text { Heavy } \\
\text { Drinking in } \\
\text { Past Two } \\
\text { Weeks }\end{array}$ \\
\hline Beer Price & \multicolumn{3}{c||}{$\begin{array}{c}\text { Panel A: } \\
\text { Full Sample }\end{array}$} \\
\cline { 2 - 4 } Minimum Legal Drinking Age & -10.355 & -9.063 & -9.221 \\
Marijuana Decriminalization & $(-3.70)$ & $(-3.13)$ & $(-2.67)$ \\
& -0.087 & -0.074 & -0.013 \\
Retail Commercial Grade & $(-1.24)$ & $(-1.02)$ & $(-0.16)$ \\
Marijuana Price & 0.015 & 0.014 & 0.034 \\
Chi-Squared & $(0.54)$ & $(0.47)$ & $(0.97)$ \\
\hline & 0.0001 & 0.001 & 0.002 \\
& $(0.22)$ & $(2.08)$ & $(3.13)$ \\
Beer Price & 1129.35 & 937.23 & 838.48 \\
\hline Minimum Legal Drinking Age & & Panel B: & \\
& & Restricted & \\
Marijuana Decriminalization & -0.080 & -0.118 & -0.055 \\
& $(-1.03)$ & $(-1.48)$ & $(-0.58)$ \\
Retail Commercial Grade & -0.022 & -0.079 & -0.082 \\
Marijuana Price & $(-0.52)$ & $(-1.80)$ & $(-1.55)$ \\
Chi-Squared & 0.0003 & 0.001 & 0.002 \\
\hline & $(0.38)$ & $(1.40)$ & $(2.35)$ \\
\hline
\end{tabular}

$n=11,281 ; 6,272$ 
Table 3 (concluded)

Beer and Marijuana Prices, Drinking Ages, and Marijuana Decriminalization

\begin{tabular}{|c|c|c|c|}
\hline Variable & $\begin{array}{c}\text { Drinking } \\
\text { in the Past } \\
\text { Year }\end{array}$ & $\begin{array}{c}\text { Drinking } \\
\text { in the Past } \\
\text { Month } \\
\end{array}$ & $\begin{array}{c}\text { Heavy } \\
\text { Drinking in } \\
\text { Past Two } \\
\text { Weeks } \\
\end{array}$ \\
\hline & \multicolumn{3}{|c|}{$\begin{array}{c}\text { Panel A: } \\
\text { Full Sample }\end{array}$} \\
\hline Beer Price & $\begin{array}{r}-9.544 \\
(-3.35)\end{array}$ & $\begin{array}{l}-8.196 \\
(-2.79)\end{array}$ & $\begin{array}{l}-8.121 \\
(-2.32)\end{array}$ \\
\hline Minimum Legal Drinking Age & $\begin{array}{l}-0.150 \\
(-2.24)\end{array}$ & $\begin{array}{r}-0.150 \\
(-2.16)\end{array}$ & $\begin{array}{r}-0.134 \\
(-1.62)\end{array}$ \\
\hline Marijuana Decriminalization & $\begin{array}{r}-0.042 \\
(-1.67)\end{array}$ & $\begin{array}{l}-0.053 \\
(-2.05)\end{array}$ & $\begin{array}{l}-0.065 \\
(-2.09)\end{array}$ \\
\hline Retail Sinsemilla Marijuana Price & $\begin{array}{l}-0.001 \\
(-3.93)\end{array}$ & $\begin{array}{l}-0.001 \\
(-3.69)\end{array}$ & $\begin{array}{l}-0.001 \\
(-2.54)\end{array}$ \\
\hline \multirow[t]{2}{*}{ Chi-Squared } & 1120.94 & 938.22 & 841.06 \\
\hline & \multicolumn{3}{|c|}{$\begin{array}{l}\text { Panel B: } \\
\text { Restricted } \\
\text { Sample }\end{array}$} \\
\hline Beer Price & $\begin{array}{l}-6.387 \\
(-1.92)\end{array}$ & $\begin{array}{l}-8.604 \\
(-2.50)\end{array}$ & $\begin{array}{c}-10.179 \\
(-2.48)\end{array}$ \\
\hline Minimum Legal Drinking Age & $\begin{array}{l}-0.050 \\
(-0.69)\end{array}$ & $\begin{array}{l}-0.119 \\
(-1.57)\end{array}$ & $\begin{array}{l}-0.131 \\
(-1.45)\end{array}$ \\
\hline Marijuana Decriminalization & $\begin{array}{l}0.030 \\
(0.64)\end{array}$ & $\begin{array}{l}-0.048 \\
(-1.00)\end{array}$ & $\begin{array}{l}-0.128 \\
(-2.21)\end{array}$ \\
\hline Retail Sinsemilla Marijuana Price & $\begin{array}{l}-0.001 \\
(-2.00)\end{array}$ & $\begin{array}{l}-0.001 \\
(-2.09)\end{array}$ & $\begin{array}{c}-0.0003 \\
(-0.66)\end{array}$ \\
\hline Chi-Squared & 697.50 & 574.95 & 557.75 \\
\hline
\end{tabular}

$n=11,783 ; 6,272$ 
Table 4

Policy Simulations

Drinking Frequency and the Probability of Heavy Drinking

\begin{tabular}{|c|c|c|c|}
\hline Policy Simulation & $\begin{array}{c}\text { Drinking } \\
\text { in the Past } \\
\text { Year }\end{array}$ & $\begin{array}{c}\text { Drinking } \\
\text { in the Past } \\
\text { Month }\end{array}$ & $\begin{array}{c}\text { Heavy } \\
\text { Drinking in } \\
\text { Past Two } \\
\text { Weeks }\end{array}$ \\
\hline & & $\begin{array}{c}\text { Panel A: } \\
\text { Pooled } 1982 \\
\text { and } 1989 \\
\text { Sample }\end{array}$ & \\
\hline \multicolumn{4}{|l|}{ Inflation Tax Policy } \\
\hline Abstainers & $+8.42 \%$ & $+4.35 \%$ & $+1.25 \%$ \\
\hline Infrequent Drinkers & $+2.15 \%$ & $-0.65 \%$ & -- \\
\hline Fairly Frequent Drinkers & $-2.71 \%$ & $-3.78 \%$ & -- \\
\hline Frequent (Heavy) Drinkers & $-7.49 \%$ & $-6.57 \%$ & $-2.28 \%$ \\
\hline \multicolumn{4}{|l|}{ Nationwide Criminalization } \\
\hline Abstainers & $-3.44 \%$ & $-3.11 \%$ & $-1.93 \%$ \\
\hline Infrequent Drinkers & $-0.97 \%$ & $+0.38 \%$ & -- \\
\hline Fairly Frequent Drinkers & $+1.10 \%$ & $+2.74 \%$ & -- \\
\hline Frequent (Heavy) Drinkers & $+3.35 \%$ & $+4.45 \%$ & $+3.53 \%$ \\
\hline \multicolumn{4}{|l|}{ Nationwide Decriminalization } \\
\hline Abstainers & $+8.31 \%$ & $+7.36 \%$ & $+4.38 \%$ \\
\hline Infrequent Drinkers & $+2.13 \%$ & $-1.17 \%$ & -- \\
\hline Fairly Frequent Drinkers & $-2.67 \%$ & $-6.37 \%$ & - \\
\hline Frequent (Heavy) Drinkers & $-7.39 \%$ & $-10.85 \%$ & $-8.02 \%$ \\
\hline \multicolumn{4}{|l|}{ Marijuana Price Reduction } \\
\hline Abstainers & -- & - & -- \\
\hline Infrequent Drinkers & -. & -- & -- \\
\hline Fairly Frequent Drinkers & - & -. & - \\
\hline Frequent (Heavy) Drinkers & -- & -- & -- \\
\hline
\end{tabular}


Table 4 (continued)

Policy Simulations

\begin{tabular}{|c|c|c|c|}
\hline Policy Simulation & $\begin{array}{c}\text { Drinking } \\
\text { in the Past } \\
\text { Year } \\
\end{array}$ & $\begin{array}{c}\text { Drinking } \\
\text { in the Past } \\
\text { Month } \\
\end{array}$ & $\begin{array}{c}\text { Heavy } \\
\text { Drinking in } \\
\text { Past Two } \\
\text { Weeks }\end{array}$ \\
\hline & & $\begin{array}{l}\text { Panel B.1: } \\
\text { 1989 Sample, } \\
\text { No Marijuana } \\
\text { Price } \\
\end{array}$ & \\
\hline \multicolumn{4}{|l|}{ Inflation Tax Policy } \\
\hline $\begin{array}{l}\text { Abstainers } \\
\text { Infrequent Drinkers } \\
\text { Fairly Frequent Drinkers } \\
\text { Frequent (Heavy) Drinkers }\end{array}$ & $\begin{array}{l}+7.68 \% \\
+1.54 \% \\
-3.20 \% \\
-7.69 \%\end{array}$ & $\begin{array}{l}+3.97 \% \\
-1.14 \% \\
-4.27 \% \\
-6.94 \%\end{array}$ & $\begin{array}{c}+2.01 \% \\
-- \\
-. . \\
-4.35 \%\end{array}$ \\
\hline \multicolumn{4}{|l|}{ Nationwide Criminalization } \\
\hline $\begin{array}{l}\text { Abstainers } \\
\text { Infrequent Drinkers } \\
\text { Fairly Frequent Drinkers } \\
\text { Frequent (Heavy) Drinkers }\end{array}$ & $\begin{array}{l}-3.29 \% \\
-0.74 \% \\
+1.38 \% \\
+3.55 \%\end{array}$ & $\begin{array}{l}-2.42 \% \\
+0.64 \% \\
+2.64 \% \\
+4.45 \%\end{array}$ & $\begin{array}{c}-1.37 \% \\
-- \\
-- \\
+2.96 \%\end{array}$ \\
\hline \multicolumn{4}{|l|}{ Nationwide Decriminalization } \\
\hline $\begin{array}{l}\text { Abstainers } \\
\text { Infrequent Drinkers } \\
\text { Fairly Frequent Drinkers } \\
\text { Frequent (Heavy) Drinkers }\end{array}$ & $\begin{array}{l}+8.10 \% \\
+1.62 \% \\
-3.37 \% \\
-8.09 \%\end{array}$ & $\begin{array}{l}+5.85 \% \\
-1.72 \% \\
-6.24 \% \\
-10.03 \%\end{array}$ & $\begin{array}{c}+3.19 \% \\
-- \\
-- \\
-6.89 \%\end{array}$ \\
\hline \multicolumn{4}{|l|}{ Marijuana Price Reduction } \\
\hline $\begin{array}{l}\text { Abstainers } \\
\text { Infrequent Drinkers } \\
\text { Fairly Frequent Drinkers } \\
\text { Frequent (Heavy) Drinkers }\end{array}$ & $\begin{array}{l}-- \\
-- \\
- \\
-\end{array}$ & $\begin{array}{l}-- \\
-- \\
--\end{array}$ & $\begin{array}{l}-- \\
-- \\
--\end{array}$ \\
\hline
\end{tabular}


Table 4 (continued)

Policy Simulations

\begin{tabular}{|c|c|c|c|}
\hline Policy Simulation & $\begin{array}{l}\text { Drinking } \\
\text { in the Past } \\
\text { Year }\end{array}$ & $\begin{array}{c}\text { Drinking } \\
\text { in the Past } \\
\text { Month }\end{array}$ & $\begin{array}{l}\text { Heavy } \\
\text { Drinking in } \\
\text { Past Two } \\
\text { Weeks }\end{array}$ \\
\hline & & $\begin{array}{c}\text { Panel B.2: } \\
1989 \text { Sample, } \\
\text { Wholesale } \\
\text { Commercial } \\
\text { Price }\end{array}$ & \\
\hline \multicolumn{4}{|l|}{ Inflation Tax Policy } \\
\hline $\begin{array}{l}\text { Abstainers } \\
\text { Infrequent Drinkers } \\
\text { Fairly Frequent Drinkers } \\
\text { Frequent (Heavy) Drinkers }\end{array}$ & $\begin{array}{l}+6.02 \% \\
+1.23 \% \\
-2.51 \% \\
-6.11 \%\end{array}$ & $\begin{array}{l}+3.01 \% \\
-0.85 \% \\
-3.25 \% \\
-5.30 \%\end{array}$ & $\begin{array}{c}+1.35 \% \\
- \\
- \\
-2.92 \%\end{array}$ \\
\hline \multicolumn{4}{|l|}{ Nationwide Criminalization } \\
\hline $\begin{array}{l}\text { Abstainers } \\
\text { Infrequent Drinkers } \\
\text { Fairly Frequent Drinkers } \\
\text { Frequent (Heavy) Drinkers }\end{array}$ & $\begin{array}{l}-2.37 \% \\
-0.53 \% \\
+0.99 \% \\
+2.54 \%\end{array}$ & $\begin{array}{l}-1.87 \% \\
+0.50 \% \\
+2.04 \% \\
+3.42 \%\end{array}$ & $\begin{array}{c}-1.00 \% \\
-- \\
-\overline{-} \\
+2.16 \%\end{array}$ \\
\hline \multicolumn{4}{|l|}{ Nationwide Decriminalization } \\
\hline $\begin{array}{l}\text { Abstainers } \\
\text { Infrequent Drinkers } \\
\text { Fairly Frequent Drinkers } \\
\text { Frequent (Heavy) Drinkers }\end{array}$ & $\begin{array}{l}+5.78 \% \\
+1.19 \% \\
-2.42 \% \\
-5.87 \%\end{array}$ & $\begin{array}{l}+4.50 \% \\
-1.30 \% \\
-4.83 \% \\
-7.81 \%\end{array}$ & $\begin{array}{c}+2.33 \% \\
- \\
- \\
-5.05 \%\end{array}$ \\
\hline \multicolumn{4}{|l|}{ Marijuana Price Reduction } \\
\hline $\begin{array}{l}\text { Abstainers } \\
\text { Infrequent Drinkers } \\
\text { Fairly Frequent Drinkers } \\
\text { Frequent (Heavy) Drinkers }\end{array}$ & $\begin{array}{l}+6.83 \% \\
+1.39 \% \\
-2.85 \% \\
-6.89 \%\end{array}$ & $\begin{array}{l}+3.98 \% \\
-1.14 \% \\
-4.28 \% \\
-6.95 \%\end{array}$ & $\begin{array}{c}+2.65 \% \\
- \\
- \\
-5.74 \%\end{array}$ \\
\hline
\end{tabular}


Table 4 (continued)

Policy Simulations

\begin{tabular}{|c|c|c|c|}
\hline Policy Simulation & $\begin{array}{l}\text { Drinking } \\
\text { in the Past } \\
\text { Year }\end{array}$ & $\begin{array}{l}\text { Drinking } \\
\text { in the Past } \\
\text { Month }\end{array}$ & $\begin{array}{l}\text { Heavy } \\
\text { Drinking in } \\
\text { Past Two } \\
\text { Weeks }\end{array}$ \\
\hline & & $\begin{array}{l}\text { Panel B.3: } \\
\text { 1989 Sample, } \\
\text { Wholesale } \\
\text { Sinsemilla } \\
\text { Price } \\
\end{array}$ & \\
\hline \multicolumn{4}{|l|}{ Inflation Tax Policy } \\
\hline $\begin{array}{l}\text { Abstainers } \\
\text { Infrequent Drinkers } \\
\text { Fairly Frequent Drinkers } \\
\text { Frequent (Heavy) Drinkers }\end{array}$ & $\begin{array}{l}+3.59 \% \\
+0.72 \% \\
-1.56 \% \\
-3.77 \%\end{array}$ & $\begin{array}{l}+0.71 \% \\
-0.20 \% \\
-0.77 \% \\
-1.28 \%\end{array}$ & $\begin{array}{c}-0.33 \% \\
- \\
-\overline{-} \\
+0.71 \%\end{array}$ \\
\hline \multicolumn{4}{|l|}{ Nationwide Criminalization } \\
\hline $\begin{array}{l}\text { Abstainers } \\
\text { Infrequent Drinkers } \\
\text { Fairly Frequent Drinkers } \\
\text { Frequent (Heavy) Drinkers }\end{array}$ & $\begin{array}{l}-4.22 \% \\
-0.92 \% \\
+1.85 \% \\
+4.69 \%\end{array}$ & $\begin{array}{l}-3.27 \% \\
+0.85 \% \\
+3.57 \% \\
+6.05 \%\end{array}$ & $\begin{array}{c}-2.01 \% \\
-- \\
-- \\
+4.35 \%\end{array}$ \\
\hline \multicolumn{4}{|l|}{ Nationwide Decriminalization } \\
\hline $\begin{array}{l}\text { Abstainers } \\
\text { Infrequent Drinkers } \\
\text { Fairly Frequent Drinkers } \\
\text { Frequent (Heavy) Drinkers }\end{array}$ & $\begin{array}{l}+10.50 \% \\
+1.94 \% \\
-4.54 \% \\
-10.54 \%\end{array}$ & $\begin{array}{l}+7.88 \% \\
-2.38 \% \\
-8.42 \% \\
-13.36 \%\end{array}$ & $\begin{array}{c}+4.62 \% \\
- \\
- \\
-10.01 \%\end{array}$ \\
\hline \multicolumn{4}{|l|}{ Marijuana Price Reduction } \\
\hline $\begin{array}{l}\text { Abstainers } \\
\text { Infrequent Drinkers } \\
\text { Fairly Frequent Drinkers } \\
\text { Frequent (Heavy) Drinkers }\end{array}$ & $\begin{array}{l}+4.81 \% \\
+0.95 \% \\
-2.09 \% \\
-5.01 \%\end{array}$ & $\begin{array}{l}+3.97 \% \\
-1.14 \% \\
-4.28 \% \\
-6.95 \%\end{array}$ & $\begin{array}{c}+2.79 \% \\
- \\
-- \\
-6.04 \%\end{array}$ \\
\hline
\end{tabular}


Table 4 (continued)

Policy Simulations

\begin{tabular}{|c|c|c|c|}
\hline Policy Simulation & $\begin{array}{c}\text { Drinking } \\
\text { in the Past } \\
\text { Year }\end{array}$ & $\begin{array}{c}\text { Drinking } \\
\text { in the Past } \\
\text { Month }\end{array}$ & $\begin{array}{l}\text { Heavy } \\
\text { Drinking in } \\
\text { Past Two } \\
\text { Weeks }\end{array}$ \\
\hline & & $\begin{array}{c}\text { Panel B.4: } \\
1989 \text { Sample, } \\
\text { Retail } \\
\text { Commercial } \\
\text { Price } \\
\end{array}$ & \\
\hline \multicolumn{4}{|l|}{ Inflation Tax Policy } \\
\hline $\begin{array}{l}\text { Abstainers } \\
\text { Intrequent Drinkers } \\
\text { Fairly Frequent Drinkers } \\
\text { Frequent (Heavy) Drinkers }\end{array}$ & $\begin{array}{l}+7.72 \% \\
+1.65 \% \\
-3.04 \% \\
-7.52 \%\end{array}$ & $\begin{array}{l}+5.04 \% \\
-0.10 \% \\
-3.29 \% \\
-6.28 \%\end{array}$ & $\begin{array}{c}+2.29 \% \\
-- \\
-- \\
-4.66 \%\end{array}$ \\
\hline \multicolumn{4}{|l|}{ Nationwide Criminalization } \\
\hline $\begin{array}{l}\text { Abstainers } \\
\text { Infrequent Drinkers } \\
\text { Fairly Frequent Drinkers } \\
\text { Frequent (Heavy) Drinkers }\end{array}$ & $\begin{array}{l}+0.57 \% \\
+0.13 \% \\
-0.22 \% \\
-0.58 \%\end{array}$ & $\begin{array}{l}+0.38 \% \\
-0.00 \% \\
-0.25 \% \\
-0.50 \%\end{array}$ & $\begin{array}{c}+0.43 \% \\
-- \\
-- \\
-0.88 \%\end{array}$ \\
\hline \multicolumn{4}{|l|}{ Nationwide Decriminalization } \\
\hline $\begin{array}{l}\text { Abstainers } \\
\text { Intrequent Drinkers } \\
\text { Fairly Frequent Drinkers } \\
\text { Frequent (Heavy) Drinkers }\end{array}$ & $\begin{array}{l}-1.81 \% \\
-0.42 \% \\
+0.72 \% \\
+1.88 \%\end{array}$ & $\begin{array}{l}-1.23 \% \\
+0.00 \% \\
+0.80 \% \\
+1.59 \%\end{array}$ & $\begin{array}{c}-1.40 \% \\
- \\
- \\
+2.84 \%\end{array}$ \\
\hline \multicolumn{4}{|l|}{ Marijuana Price Reduction } \\
\hline $\begin{array}{l}\text { Abstainers } \\
\text { Infrequent Drinkers } \\
\text { Fairly Frequent Drinkers } \\
\text { Frequent (Heavy) Drinkers }\end{array}$ & $\begin{array}{l}+0.31 \% \\
+0.07 \% \\
-0.12 \% \\
-0.31 \%\end{array}$ & $\begin{array}{l}+2.24 \% \\
-0.03 \% \\
-1.46 \% \\
-2.84 \%\end{array}$ & $\begin{array}{c}+1.81 \% \\
- \\
- \\
-3.69 \%\end{array}$ \\
\hline
\end{tabular}


Table 4 (concluded)

Policy Simulations

\begin{tabular}{|c|c|c|c|}
\hline Policy Simulation & $\begin{array}{l}\text { Drinking } \\
\text { in the Past } \\
\text { Year }\end{array}$ & $\begin{array}{c}\text { Drinking } \\
\text { in the Past } \\
\text { Month }\end{array}$ & $\begin{array}{l}\text { Heavy } \\
\text { Drinking in } \\
\text { Past Two } \\
\text { Weeks }\end{array}$ \\
\hline & & $\begin{array}{c}\text { Panel B.5: } \\
1989 \text { Sample, } \\
\text { Retail } \\
\text { Sinsemilla } \\
\text { Price } \\
\end{array}$ & \\
\hline \multicolumn{4}{|l|}{ Inflation Tax Policy } \\
\hline $\begin{array}{l}\text { Abstainers } \\
\text { Infrequent Drinkers } \\
\text { Fairly Frequent Drinkers } \\
\text { Frequent (Heavy) Drinkers }\end{array}$ & $\begin{array}{l}+7.02 \% \\
+1.51 \% \\
-2.78 \% \\
-6.90 \%\end{array}$ & $\begin{array}{l}+3.77 \% \\
-0.98 \% \\
-3.91 \% \\
-6.43 \%\end{array}$ & $\begin{array}{c}+1.98 \% \\
- \\
- \\
-4.10 \%\end{array}$ \\
\hline \multicolumn{4}{|l|}{ Nationwide Criminalization } \\
\hline $\begin{array}{l}\text { Abstainers } \\
\text { Infrequent Drinkers } \\
\text { Fairly Frequent Drinkers } \\
\text { Frequent (Heavy) Drinkers }\end{array}$ & $\begin{array}{l}-2.07 \% \\
-0.49 \% \\
+0.82 \% \\
+2.17 \%\end{array}$ & $\begin{array}{l}-1.68 \% \\
+0.40 \% \\
+1.76 \% \\
+2.99 \%\end{array}$ & $\begin{array}{c}-1.11 \% \\
- \\
- \\
+2.30 \%\end{array}$ \\
\hline \multicolumn{4}{|l|}{ Nationwide Decriminalization } \\
\hline $\begin{array}{l}\text { Abstainers } \\
\text { Infrequent Drinkers } \\
\text { Fairly Frequent Drinkers } \\
\text { Frequent (Heavy) Drinkers }\end{array}$ & $\begin{array}{l}+4.58 \% \\
+1.01 \% \\
-1.82 \% \\
-4.57 \%\end{array}$ & $\begin{array}{l}+3.65 \% \\
-0.95 \% \\
-3.79 \% \\
-6.23 \%\end{array}$ & $\begin{array}{c}+2.35 \% \\
-- \\
-4.89 \%\end{array}$ \\
\hline \multicolumn{4}{|l|}{ Marijuana Price Reduction } \\
\hline $\begin{array}{l}\text { Abstainers } \\
\text { Infrequent Drinkers } \\
\text { Fairly Frequent Drinkers } \\
\text { Frequent (Heavy) Drinkers }\end{array}$ & $\begin{array}{l}-5.32 \% \\
-1.30 \% \\
+2.12 \% \\
+5.71 \%\end{array}$ & $\begin{array}{l}-3.49 \% \\
+0.78 \% \\
+3.52 \% \\
+6.03 \%\end{array}$ & $\begin{array}{c}-1.49 \% \\
-- \\
- \\
+3.10 \%\end{array}$ \\
\hline
\end{tabular}


Table 5

Probit Estimates of the Probability of a Motor Vehicle Accident Beer and Marijuana Prices, Drinking Ages, and Marijuana Decriminalization

\begin{tabular}{|c|c|c|c|}
\hline Variable & $\begin{array}{c}\text { Pooled } 1982 \\
\text { and } 1989 \\
\text { Samples }\end{array}$ & $\begin{array}{c}1989 \text { Sample } \\
\text { No Marijuana } \\
\text { Prices }\end{array}$ & $\begin{array}{l}1989 \text { Sample } \\
\text { Wholesale } \\
\text { Commercial } \\
\text { Marijuana } \\
\text { Prices }\end{array}$ \\
\hline & \multicolumn{3}{|c|}{ Panel A } \\
\hline Beer Price & $\begin{array}{c}-10.333 \\
(-3.78)\end{array}$ & $\begin{array}{c}-10.394 \\
(-2.95)\end{array}$ & $\begin{array}{l}-8.689 \\
(-2.44)\end{array}$ \\
\hline Minimum Legal Drinking Age & $\begin{array}{c}0.030 \\
(2.89)\end{array}$ & $\begin{array}{l}-0.067 \\
(-0.79)\end{array}$ & $\begin{array}{l}-0.034 \\
(-0.39)\end{array}$ \\
\hline Lower Border Age & $\begin{array}{r}0.001 \\
(0.05)\end{array}$ & $-\cdots$ & --- \\
\hline Marijuana Decriminalization & $\begin{array}{l}-0.053 \\
(-2.66)\end{array}$ & $\begin{array}{l}-0.112 \\
(-3.90)\end{array}$ & $\begin{array}{l}-0.098 \\
(-3.38)\end{array}$ \\
\hline Marijuana Price & --- & ---- & $\begin{array}{c}0.0002 \\
(3.10)\end{array}$ \\
\hline \multirow[t]{2}{*}{ Chi-Squared } & 929.80 & 399.22 & 408.82 \\
\hline & \multicolumn{3}{|c|}{ Panel B } \\
\hline Beer Price & $\begin{array}{r}-9.973 \\
(-3.64)\end{array}$ & $\begin{array}{l}-9.660 \\
(-2.73)\end{array}$ & $\begin{array}{l}-8.076 \\
(-2.26)\end{array}$ \\
\hline Minimum Legal Drinking Age & $\begin{array}{l}0.031 \\
(2.94)\end{array}$ & $\begin{array}{l}-0.063 \\
(-0.74)\end{array}$ & $\begin{array}{l}-0.031 \\
(-0.36)\end{array}$ \\
\hline Lower Border Age & $\begin{array}{l}0.001 \\
(0.05)\end{array}$ & - & --- \\
\hline Marijuana Decriminalization & $\begin{array}{l}-0.058 \\
(-2.88)\end{array}$ & $\begin{array}{l}-0.117 \\
(-4.05)\end{array}$ & $\begin{array}{c}-0.103 \\
(-3.54)\end{array}$ \\
\hline Marijuana Price & $\cdots$ & -..- & $\begin{array}{c}0.0002 \\
(2.97)\end{array}$ \\
\hline Chi-Squared & 938.35 & 404.99 & 413.81 \\
\hline
\end{tabular}


Table 5 (continued)

Beer and Marijuana Prices, Drinking Ages, and Marijuana Decriminalization

\begin{tabular}{|c|c|c|c|}
\hline Variable & $\begin{array}{c}1989 \text { Sample } \\
\text { Wholesale } \\
\text { Sinsemilla } \\
\text { Marijuana } \\
\text { Price } \\
\end{array}$ & $\begin{array}{c}1989 \text { Sample } \\
\text { Retail } \\
\text { Commercial } \\
\text { Marijuana } \\
\text { Price } \\
\end{array}$ & $\begin{array}{c}1989 \text { Sample } \\
\text { Retail } \\
\text { Sinsemilla } \\
\text { Marijuana } \\
\text { Price } \\
\end{array}$ \\
\hline & \multicolumn{3}{|c|}{ Panel A } \\
\hline Beer Price & $\begin{array}{l}-6.970 \\
(-1.76)\end{array}$ & $\begin{array}{r}-11.611 \\
(-3.28)\end{array}$ & $\begin{array}{l}-8.660 \\
(-2.42)\end{array}$ \\
\hline Minimum Legal Drinking Age & $\begin{array}{l}-0.068 \\
(-0.80)\end{array}$ & $\begin{array}{l}0.053 \\
(0.59)\end{array}$ & $\begin{array}{l}-0.116 \\
(-1.34)\end{array}$ \\
\hline Lower Border Age & ב- & - & $\overline{-}$ \\
\hline Marijuana Decriminalization & $\begin{array}{l}-0.126 \\
(-4.24)\end{array}$ & $\begin{array}{l}-0.035 \\
(-0.97)\end{array}$ & $\begin{array}{l}-0.188 \\
(-5.84)\end{array}$ \\
\hline Marijuana Price & $\begin{array}{l}0.0001 \\
(1.86)\end{array}$ & $\begin{array}{l}0.003 \\
(5.30)\end{array}$ & $\begin{array}{l}0.001 \\
(3.57)\end{array}$ \\
\hline \multirow[t]{2}{*}{ Chi-Squared } & 402.69 & 359.31 & 333.07 \\
\hline & \multicolumn{3}{|c|}{ Panel B } \\
\hline Beer Price & $\begin{array}{l}-6.400 \\
(-1.61)\end{array}$ & $\begin{array}{r}-10.981 \\
(-3.09)\end{array}$ & $\begin{array}{l}-7.966 \\
(-2.22)\end{array}$ \\
\hline Minimum Legal Drinking Age & $\begin{array}{l}-0.065 \\
(-0.76)\end{array}$ & $\begin{array}{l}0.057 \\
(0.84)\end{array}$ & $\begin{array}{l}-0.112 \\
(-1.30)\end{array}$ \\
\hline Lower Border Age & --.- & $\cdots$ & ב-. \\
\hline Marijuana Decriminalization & $\begin{array}{l}-0.130 \\
(-4.37)\end{array}$ & $\begin{array}{r}-0.038 \\
(-1.06)\end{array}$ & $\begin{array}{l}-0.192 \\
(-5.96)\end{array}$ \\
\hline Marijuana Price & $\begin{array}{l}0.0001 \\
(1.78)\end{array}$ & $\begin{array}{l}0.003 \\
(5.33)\end{array}$ & $\begin{array}{l}0.001 \\
(3.55)\end{array}$ \\
\hline Chi-Squared & 408.17 & 363.38 & 337.87 \\
\hline
\end{tabular}


Table 5 (concluded)

Beer and Marijuana Prices, Drinking Ages, and Marijuana Decriminalization Restricted 1989 Sample

\begin{tabular}{|c|c|c|c|c|}
\hline Variable & $\begin{array}{l}\text { Wholesale } \\
\text { Commercial } \\
\text { Marijuana } \\
\text { Price }\end{array}$ & $\begin{array}{c}\text { Wholesale } \\
\text { Sinsemilla } \\
\text { Marijuana } \\
\text { Price } \\
\end{array}$ & $\begin{array}{c}\text { Retail } \\
\text { Commercial } \\
\text { Marijuana } \\
\text { Price }\end{array}$ & $\begin{array}{c}\text { Retail } \\
\text { Sinsemilla } \\
\text { Marijuana } \\
\text { Price }\end{array}$ \\
\hline \multicolumn{5}{|c|}{ Panel A } \\
\hline Beer Price & $\begin{array}{l}-9.568 \\
(-2.28)\end{array}$ & $\begin{array}{l}-7.978 \\
(-1.61)\end{array}$ & $\begin{array}{l}-9.661 \\
(-2.30)\end{array}$ & $\begin{array}{l}-8.464 \\
(-2.07)\end{array}$ \\
\hline $\begin{array}{l}\text { Minimum Legal } \\
\text { Drinking Age }\end{array}$ & $\begin{array}{l}-0.044 \\
(-0.48)\end{array}$ & $\begin{array}{l}-0.054 \\
(-0.60)\end{array}$ & $\begin{array}{l}0.091 \\
(0.90)\end{array}$ & $\begin{array}{l}-0.182 \\
(-1.91)\end{array}$ \\
\hline $\begin{array}{l}\text { Marijuana } \\
\text { Decriminalization }\end{array}$ & $\begin{array}{l}-0.142 \\
(-3.19)\end{array}$ & $\begin{array}{l}-0.152 \\
(-3.40)\end{array}$ & $\begin{array}{l}-0.037 \\
(-0.68)\end{array}$ & $\begin{array}{l}-0.338 \\
(-5.65)\end{array}$ \\
\hline Marijuana Price & $\begin{array}{c}0.0001 \\
(0.71)\end{array}$ & $\begin{array}{c}0.00003 \\
(0.69)\end{array}$ & $\begin{array}{l}0.003 \\
(3.55)\end{array}$ & $\begin{array}{l}0.002 \\
(4.78)\end{array}$ \\
\hline Chi-Squared & 209.81 & 209.78 & 221.89 & 232.04 \\
\hline \multicolumn{5}{|c|}{ Panel B } \\
\hline Beer Price & $\begin{array}{l}-8.948 \\
(-2.12)\end{array}$ & $\begin{array}{l}-7.517 \\
(-1.52)\end{array}$ & $\begin{array}{l}-9.040 \\
(-2.15)\end{array}$ & $\begin{array}{l}-7.907 \\
(-1.87)\end{array}$ \\
\hline $\begin{array}{l}\text { Minimum Legal } \\
\text { Drinking Age }\end{array}$ & $\begin{array}{l}-0.045 \\
(-0.49)\end{array}$ & $\begin{array}{l}-0.054 \\
(-0.59)\end{array}$ & $\begin{array}{l}0.088 \\
(0.88)\end{array}$ & $\begin{array}{l}-0.180 \\
(-1.88)\end{array}$ \\
\hline $\begin{array}{l}\text { Marijuana } \\
\text { Decriminalization }\end{array}$ & $\begin{array}{l}-0.153 \\
(-3.40)\end{array}$ & $\begin{array}{l}-0.161 \\
(-3.57)\end{array}$ & $\begin{array}{l}-0.048 \\
(-0.89)\end{array}$ & $\begin{array}{l}-0.342 \\
(-5.73)\end{array}$ \\
\hline Marijuana Price & $\begin{array}{c}0.00004 \\
(0.55)\end{array}$ & $\begin{array}{c}0.00003 \\
(0.65)\end{array}$ & $\begin{array}{l}0.003 \\
(3.46)\end{array}$ & $\begin{array}{l}0.002 \\
(4.68)\end{array}$ \\
\hline Chi-Squared & 215.25 & 215.31 & 226.92 & 236.75 \\
\hline
\end{tabular}


Table 6

Weighted Least Squares Estimates of Youth Motor Vehicle Accident Fatality Rates Beer Taxes, Drinking Ages, and Marijuana Decriminalization

\begin{tabular}{|c|c|c|c|}
\hline Variable & $\begin{array}{c}\text { Total Fatality } \\
\text { Rate }\end{array}$ & $\begin{array}{l}\text { Night Driver } \\
\text { Fatality Rate }\end{array}$ & $\begin{array}{c}\text { Alcohol } \\
\text { Involved Driver } \\
\text { Fatality Rate }\end{array}$ \\
\hline & \multicolumn{3}{|c|}{$\begin{array}{c}\text { Panel A: } \\
\text { Ages 15-24 }\end{array}$} \\
\hline Beer Tax & $\begin{array}{c}-10.513 \\
(-6.25)\end{array}$ & $\begin{array}{c}-10.401 \\
(-4.92)\end{array}$ & $\begin{array}{c}-12.793 \\
(-4.98)\end{array}$ \\
\hline Minimum Legal Drinking Age & $\begin{array}{l}-0.012 \\
(-1.82)\end{array}$ & $\begin{array}{l}-0.031 \\
(-3.94)\end{array}$ & $\begin{array}{l}-0.015 \\
(-1.52)\end{array}$ \\
\hline Marijuana Decriminalization & $\begin{array}{l}-0.055 \\
(-3.27)\end{array}$ & $\begin{array}{l}-0.125 \\
(-5.99)\end{array}$ & $\begin{array}{l}-0.050 \\
(-1.97)\end{array}$ \\
\hline R-Squared & 0.538 & 0.428 & 0.649 \\
\hline $\mathrm{F}$ & 29.04 & 18.98 & 42.81 \\
\hline \multirow[t]{2}{*}{$\mathrm{n}$} & 650 & 650 & 565 \\
\hline & \multicolumn{3}{|c|}{$\begin{array}{c}\text { Panel B: } \\
\text { Ages 18-20 }\end{array}$} \\
\hline Beer Tax & $\begin{array}{c}-13.305 \\
(-7.15)\end{array}$ & $\begin{array}{c}-15.360 \\
(-5.69)\end{array}$ & $\begin{array}{c}-15.992 \\
(-5.76)\end{array}$ \\
\hline Minimum Legal Drinking Age & $\begin{array}{l}-0.030 \\
(-4.12)\end{array}$ & $\begin{array}{l}-0.070 \\
(-6.94)\end{array}$ & $\begin{array}{l}-0.041 \\
(-3.86)\end{array}$ \\
\hline Marijuana Decriminalization & $\begin{array}{l}-0.062 \\
(-3.31)\end{array}$ & $\begin{array}{l}-0.143 \\
(-5.36)\end{array}$ & $\begin{array}{l}-0.064 \\
(-2.35)\end{array}$ \\
\hline R-Squared & 0.651 & 0.561 & 0.705 \\
\hline$F$ & 45.77 & 31.48 & 54.44 \\
\hline $\mathrm{n}$ & 650 & 648 & 560 \\
\hline
\end{tabular}


Table 7

Policy Simulations: Probability of a Non-Fatal Motor Vehicle Accident

\begin{tabular}{|c|c|c|c|}
\hline Policy Simulation & $\begin{array}{l}\text { Pooled } \\
\text { Sample }\end{array}$ & $\begin{array}{l}1989 \text { Sample, } \\
\text { No Price for } \\
\text { Marijuana }\end{array}$ & $\begin{array}{c}1989 \text { Sample, } \\
\text { Wholesale } \\
\text { Commercial } \\
\text { Price }\end{array}$ \\
\hline Inflation Tax Policy & $-5.84 \%$ & $-5.57 \%$ & $-4.67 \%$ \\
\hline Nationwide Criminalization & $+2.30 \%$ & $+4.43 \%$ & $+3.92 \%$ \\
\hline Nationwide Decriminalization & $-5.23 \%$ & $-10.11 \%$ & $-8.98 \%$ \\
\hline \multirow[t]{2}{*}{ Marijuana Price Reduction } & - & - & $-3.52 \%$ \\
\hline & $\begin{array}{c}1989 \text { Sample, } \\
\text { Wholesale } \\
\text { Sinsemilla } \\
\text { Price }\end{array}$ & $\begin{array}{c}1989 \text { Sample, } \\
\text { Retail } \\
\text { Commercial } \\
\text { Price }\end{array}$ & $\begin{array}{c}1989 \text { Sample, } \\
\text { Retail } \\
\text { Sinsemilla } \\
\text { Price } \\
\end{array}$ \\
\hline Inflation Tax Policy & $-3.71 \%$ & $-6.27 \%$ & $-4.50 \%$ \\
\hline Nationwide Criminalization & $+4.94 \%$ & $+1.14 \%$ & $+7.71 \%$ \\
\hline Nationwide Decriminalization & $-11.24 \%$ & $-3.62 \%$ & $-15.62 \%$ \\
\hline Marijuana Price Reduction & $-2.25 \%$ & $-7.25 \%$ & $-4.90 \%$ \\
\hline
\end{tabular}


Table 8

Policy Simulations: Probability of a Fatal Motor Vehicle Accident

\begin{tabular}{|c|c|c|c|}
\hline Policy Simulation & $\begin{array}{c}\text { Total Fatality } \\
\text { Rate }\end{array}$ & $\begin{array}{l}\text { Night Driver } \\
\text { Fatality Rate }\end{array}$ & $\begin{array}{c}\text { Alcohol } \\
\text { Involved } \\
\text { Driver Fatality } \\
\text { Rate }\end{array}$ \\
\hline & \multicolumn{3}{|c|}{$\begin{array}{c}\text { Panel A: } \\
\text { Ages 15-24 }\end{array}$} \\
\hline Inflation Tax Policy & $\begin{array}{c}-16.18 \% \\
-2,288\end{array}$ & $\begin{array}{c}-16.02 \% \\
-375\end{array}$ & $\begin{array}{c}-19.14 \% \\
-835\end{array}$ \\
\hline Nationwide Criminalization & $\begin{array}{c}+1.58 \% \\
+224\end{array}$ & $\begin{array}{c}+3.52 \% \\
+82\end{array}$ & $\begin{array}{c}+1.40 \% \\
+61\end{array}$ \\
\hline \multirow[t]{2}{*}{ Nationwide Decriminalization } & $\begin{array}{c}-3.88 \% \\
-549 \\
\end{array}$ & $\begin{array}{c}-8.62 \% \\
-202 \\
\end{array}$ & $\begin{array}{c}-3.53 \% \\
-154\end{array}$ \\
\hline & \multicolumn{3}{|c|}{$\begin{array}{c}\text { Panel B: } \\
\text { Ages 18-20 }\end{array}$} \\
\hline Inflation Tax Policy & $\begin{array}{c}-19.94 \% \\
-1,037\end{array}$ & $\begin{array}{c}-22.59 \% \\
-194\end{array}$ & $\begin{array}{c}-23.19 \% \\
-350\end{array}$ \\
\hline Nationwide Criminalization & $\begin{array}{l}+1.77 \% \\
+92\end{array}$ & $\begin{array}{c}+3.99 \% \\
+34\end{array}$ & $\begin{array}{c}+1.78 \% \\
+27\end{array}$ \\
\hline Nationwide Decriminalization & $\begin{array}{c}-4.35 \% \\
-226\end{array}$ & $\begin{array}{c}-9.89 \% \\
-194\end{array}$ & $\begin{array}{c}-4.51 \% \\
-68\end{array}$ \\
\hline
\end{tabular}

